ISSN 2083-3725
Volume 10, No. 2, 2017
Authors' contribution/

Wkład autorów:

A. Zaplanowanie badań/

Study design

B. Zebranie danych/

Data collection

C. Analiza statystyczna/

Statistical analysis

D. Interpretacja danych/

Data interpretation

Manuscript preparation

F. Opracowanie

piśmiennictwa/

Literature search

G. Pozyskanie funduszy/

Funds collection
E. Przygotowanie tekstu/

\section{THE STRUCTURE OF RETAIL TRADE AND INTERACTIONS AMONG RETAIL NETWORK ESTABLISHMENTS (ON THE EXAMPLE OF BIAŁA PODLASKA)}

\section{STRUKTURA HANDLU DETALICZNEGO I WZAJEMNE ODDZIAŁYWANIA OBIEKTÓW SIECI HANDLOWEJ (NA PRZYKŁADZIE MIASTA BIAŁA PODLASKA)}

\author{
Mieczysław Adamowicz $^{(A, C, D, E, F, G)}$, Paweł Siedlanowski ${ }^{(B, C, D)}$
}

Pope John Paul II State School of Higher Education in Biała Podlaska

Państwowa Szkoła Wyższa im. Papieża Jana Pawła II w Białej Podlaskiej

Adamowicz M., Siedlanowski P. (2017), The structure of retail trade and interactions among retail network establishments (on the example of Biała Podlaska)/ Struktura handlu detalicznego $i$ wzajemne oddziaływania obiektów sieci handlowej (na przykładzie miasta Biała Podlaska). Economic and Regional Studies, Vol. 10, No. 2, pp. 74-95. https://doi.org/10.2478/ers-2017-0017

\section{Summary}

\section{ORIGINAL ARTICLE}

JEL code: R3, M3

Submitted:

February 2017

Accepted:

March 2017

Tables: 2

Figures: 6

References: 21

ORYGINALNY ARTYKUŁ NAUKOWY

Klasyfikacja JEL: R3, M3

Zgłoszony:

luty 2017

Zaakceptowany:

marzec 2017

Tabele: 2

Rysunki: 6

Literatura: 21 in retail trade as well as functions performed by this sector, with particular focus on large-format retail facilities. The aim of this article is to assess the state and development factors of large-format retailers in Biała Podlaska.

Materials and methods: The article was created with the application of the descriptive method and based on the literature dealing with this issue and personal research. The research material was composed of the authors' observations and a questionnaire survey conducted on the group of 100 inhabitants of Biała Podlaska.

Results: The areas of retail services supplied by the retail network, distribution and mutual interaction between the main retail facilities and the development prospects of the retail network in the city were presented.

Conclusions: The research confirms general changes in trade manifested by the expansion of super and hypermarkets, as well as discount stores, also in smaller cities, where chains adjust retail space to local conditions.

Keywords: retail trade, retail networks, large-format retail, retail trade in Biała Podlaska

\section{Streszczenie}

Przedmiot i cel pracy: Przedmiotem pracy jest przedstawienie współczesnych tendencji i zmian w handlu detalicznym oraz pełnionych przez ten sektor funkcji, ze szczególnym uwzględnieniem handlu wielkopowierzchniowego. Celem artykułu jest ocena stanu i czynników rozwoju handlu wielkopowierzchniowego w mieście Biała Podlaska.

Materiały i metody: Artykuł powstał przy zastosowaniu metody opisowej i wykorzystaniu literatury problemu oraz badań własnych. Materiał badawczy stanowiły własne obserwacje autorów oraz badanie ankietowe na 100 osobowej grupie mieszkańców miasta.

Wyniki: Przedstawiono obszary obsługi handlowej przez sieć handlowa, rozmieszczenie i wzajemne oddziaływanie głównych obiektów handlowych oraz perspektywy rozwoju sieci handlowej w mieście. Wnioski: Badania potwierdzają ogólne zmiany w handlu ujawniające się w ekspansji super i hipermarketów oraz dyskontów także w mniejszych miastach, gdzie sieci dostosowują powierzchnie handlowe do uwarunkowań lokalnych.

Słowa kluczowe: handel detaliczny, sieci handlowe, handel wielkopowierzchniowy, handel w Białej
Subject and purpose of work: The subject of this work is to present contemporary trends and changes Podlaskiej

Address for correspondence/ Adres korespondencyjny: prof. zw. dr hab. Mieczysław Adamowicz, Państwowa Szkoła Wyższa im. Papieża Jana Pawła II w Białej Podlaskiej, Wydział Nauk Ekonomicznych i Technicznych, ul. Sidorska 95/97, 21-500 Biała Podlaska, Polska; tel. +48 83 344 99 05; e-mail: adamowicz.mieczyslaw@gmail.com

Journal indexed in/ Czasopismo indeksowane w: AgEcon Search, AGRO, BazEkon, Index Copernicus Journal Master List, ICV 2015: 81,26; Polish Ministry of Science and Higher Education 2016: 9 points / AgEcon Search, AGRO, BazEkon, Index Copernicus Journal Master List ICV 2015: 81,26; Ministerstwie Nauki i Szkolnictwa Wyższego 2016: 9 punktów. Copyright: (C) 2017 Pope John Paul II State School of Higher Education in Biała Podlaska, Mieczysław Adamowicz, Paweł Siedlanowski. All articles are distributed under the terms of the Creative Commons Attribution-NonCommercial-ShareAlike 4.0 International (CC BY-NC-SA 4.0) License (http://creativecommons.org/licenses/bync-sa/4.0/), allowing third parties to copy and redistribute the material in any medium or format and to remix, transform, and build upon the material, provided the original work is properly cited and states its license. 


\section{Introduction}

Large-format retail (LRF) is still intensively expanding and becoming the main form of retail trade. The role of modern retail facilities is to organize the flow of products in a specific area, provide a wide range of assortment to choose from, create a suitable trade offer, properly stock and manage goods, maintain adequate financial liquidity, create the right atmosphere in the facility, to provide comprehensive service and professional advice as well as to provide high quality after-sale services. With the passage of time, the market position of discount stores, supermarkets and hypermarkets strengthens, while small shops, regular and specialty department stores and supermarkets selling mainly groceries are in decline. Currently, in Poland, retail trade together with associated services generates about $17 \%$ of GDP. Large-format retail also consolidates in smaller towns, where it competes with smaller retail outlets and drives them out of business. In these towns, the emergence of shopping centres can also be observed.

\section{Material and research methodology}

Two parts were distinguished in this work: theoretical and empirical. The theoretical part undertakes to characterise the term "trade" as well as the stages of its development and functions it fulfils (especially large-format retail). The second part of the study is of empirical character and analyses the equipment of a city with the retail sub-product. The location of individual business entities, as well as the target consumers of the retail offer were specified.

On the basis of the literature, the following questions were addressed:

- what is the direction of changes in retail trade,

- what is the demand for retail space in Biała Podlaska,

- what are the main factors of trade development,

- what is the location of large-format retail (LFR) facilities in the city and what are its determinants,

- what is the impact range of LRF in Biała Podlaska,

- what are the development prospects of retail space in Biała Podlaska and what are its determinants?

To this end, a questionnaire survey in a group of 100 inhabitants of the city of Biała Podlaska was conducted in order to determine the areas of retail service provided by retail networks and the interaction between the main retail facilities. The purchasing behaviour of the respondents and their comfort zones while shopping in various types of retail outlets were defined. "The study of conditions and directions of spatial planning of Biała Podlaska" and statistical data of the Central Statistical Office (GUS) were also used to analyse and evaluate the distribution and impact of retail chains.

\section{Wstęp}

Handel wielkopowierzchniowy nadal intensywnie się rozwija i staje się główną formą handlu detalicznego. Zadaniem nowoczesnych placówek handlowych jest organizowanie przepływu produktów na określonym obszarze, zapewnianie szerokiego wyboru asortymentu, kreowanie odpowiedniej oferty handlowej, odpowiednie magazynowanie i zarządzanie towarami, utrzymywanie odpowiedniej płynności finansowej, organizacja odpowiedniej atmosfery w placówce, kompleksowa obsługa oraz doradztwo jak i świadczenie wysokiej jakości usług posprzedażowych. Wraz $\mathrm{z}$ upływem czasu swoją pozycję na rynku umacniają dyskonty, supermarkety oraz hipermarkety, natomiast znacznie tracą małe sklepy, domy handlowe, domy towarowe oraz supersamy. Aktualnie w Polsce handel detalicznym wraz z towarzyszącymi usługami mu towarzyszącymi wytwarza około $17 \%$ PKB. Handel wielkopowierzchniowy umacnia się także w mniejszych miastach, gdzie konkuruje i wypiera mniejsze placówki handlowe. W tych miastach można obserwować także powstawanie centrów handlowych.

\section{Materiał i metodyka badań}

W pracy wyróżniono dwie części teoretyczną i empiryczną. W części teoretycznej dokonano charakterystyki pojęcia handel, opisano etapy jego rozwoju oraz funkcje jakie pełni (szczególnie handel wielkopowierzchniowy). Druga część pracy ma charakter empiryczny dokonano w niej analizy wyposażenia miasta w subprodukt handlowy. Wskazano lokalizacje poszczególnych podmiotów gospodarczych, a także docelowych odbiorców oferty handlowej.

Na podstawie literatury poszukiwano odpowiedzi na następujące pytania:

- w jakim kierunku podążają zmiany w handlu detalicznym,

- jak wygląda zapotrzebowanie na przestrzeń handlową w mieście Biała Podlaska,

- jakie są główne czynniki rozwoju handlu,

- jaka jest lokalizacja wielkopowierzchniowych obiektów handlowych (WOH) w mieście oraz co ją warunkuje,

- jaki jest zasięg oddziaływania WOH w Białej Podlaskiej,

- jakie są perspektywy rozwoju przestrzeni sprzedażowej w Białej Podlaskiej oraz co ją warunkuje .

W tym celu zostało przeprowadzone badanie ankietowe na próbie 100 mieszkańców miasta Biała Podlaska mające na celu określenie obszarów obsługi handlowej przez sieci handlowe miasta oraz wzajemne oddziaływanie głównych obiektów handlowych. Określono zachowania nabywcze ankietowanych oraz strefy komfortu dokonania zakupów w różnych rodzajach placówek handlowych. Do analizy i oceny rozmieszczenia oraz oddziaływania sieci handlowych wykorzystano również „Studium uwarunkowań i kierunków zagospodarowania przestrzennego miasta Biała Podlaska" oraz dane statystyczne GUS. 


\section{The essence and tendency of changes in retail trade}

Trade is an economic activity whose purpose is to mediate in the money-for-goods exchange and its activity consists in the purchase of goods for further resale (Pilarczyk 2001). It can be considered in a functional as well as an institutional approach.

Retail trade plays the most important role in the turnover of commodities, whereby goods are transferred from the exchange zone to production usage or consumption zone (Adamowicz 2015). Purchasers in retail trade are mainly individual consumers and, to a lesser extent, collective consumers and producers (Zakrzewski 1989). According to Kotler, retail may include all types of activities that are designed to sell services and products to the consumer withoutintermediaries, for their non-commercial personal use. Organisational units that conduct such sales conduct retail trade, whether they are wholesalers, manufacturers or retailers. One of the most important characteristics of retail trade, beside a large number of customers, is concluding and finalising commercial transactions, which are small in terms of their value and quantity. The payment for the purchased goods is usually immediate (Kościcka-Gębska, Tul-Krzyszczuk, Gębski 2009). Trade exchange is classified as an important branch of business and, together with repair services, it constitutes a branch of the national economy. There are various forms of retail trade that can be defined as methods of organising the relations between sellers and buyers. Most commonly, three basic forms of retail trade are distinguished: stationary, mail order and door-todoor trade (Adamowicz, Zaręba 2015).

Fixed retail outlets are used in the most widespread stationary retail. They are permanently located in one place and differ in terms of size and type of retail facility. Each retail facility has an individual construction form, specified for the individual investor (Kucharska, Twardzik 2007). At present, stationary outlets include mainly: discount stores, regular and specialty department stores, supermarkets selling mainly groceries, shops specialising in one or more types of products, all specialist stores, petrol stations, kiosks and vending machines, which are classified as small retailers (Adamowicz, Zaręba 2015).

A popular form of retail trade is door-to-door trade, with particularly developed sales from vans visiting towns during scheduled tours. Such mode of sales plays a significant role in supplying rural or camping areas, particularly where maintaining shops is difficult and unprofitable. Door-to-door trade also includes markets and bazaars.

A rapidly growing form of trade is the so-called e-commerce, that is virtual or electronic commerce. The exchange of goods occurs then through the Internet. The dominant form of e-commerce is an online shop or store which presents a commercial offer on websites, where descriptions of products, photos, multimedia or video presentations are available. The transaction is finalized electronically

\section{Istota i tendencje zmian $w$ handlu detalicznym}

Handel jest działalnością gospodarczą, której zadaniem jest pośredniczenie $\mathrm{w}$ wymianie towarowo-pieniężnej, jego działalność polega na zakupie towarów w celu dalszej odsprzedaży (Pilarczyk 2001). Można go rozpatrywać w ujęciu funkcjonalnym jak również $\mathrm{w}$ ujęciu instytucjonalnym.

Najważniejszą rolę w obrocie towarowym pełni handel detaliczny, dzięki któremu towary są przenoszone ze sfery wymiany i trafiają do sfery zużycia produkcyjnego bądź spożycia (Adamowicz 2015). Nabywcami w handlu detalicznym są głównie konsumenci indywidualni, w mniejszym stopniu konsumenci zbiorowi oraz wytwórcy (Zakrzewski 1989). Według Kotlera do sprzedaży detalicznej możemy zaliczyć wszystkie rodzaje działalności, które mają na celu sprzedaż usług i produktów bez pośredników, konsumentowi do jego niekomercyjnego osobistego użytku. Jednostki organizacyjne prowadzące taką sprzedaż nieważne czy są to hurtownicy, producenci, czy sprzedawcy detaliczni zajmują się handlem detalicznym. Jedną z ważniejszych cech handlu detalicznego, poza dużą liczbą klientów, jest zawieranie i finalizowanie niewielkich pod względem wartościowym oraz ilościowym transakcji handlowych. Za zakupione towary zapłata przeważnie jest natychmiastowa (Kościcka-Gębska, Tul-Krzyszczuk, Gębski 2009). Wymiana handlowa jest zaliczana do ważnych gałęzi działalności gospodarczej, a razem z naprawami stanowi dział gospodarki narodowej. Występują różne formy handlu detalicznego, które można zdefiniować jako sposoby organizacji kontaktów sprzedawców z kupującymi. Najczęściej wyróżnia się trzy formy podstawowe w handlu detalicznym: handel stacjonarny, wysyłkowy, oraz obwoźny (Adamowicz, Zaręba 2015).

W najbardziej rozpowszechnionym handlu stacjonarnym, są wykorzystywane stałe punkty sprzedaży detalicznej, czyli są one zlokalizowane przez cały czas w jednym miejscu i różnią się od siebie wielkością oraz rodzajem obiektu handlowego. Każdy obiekt sprzedaży detalicznej ma indywidualną, określoną dla poszczególnego inwestora, formę budowlaną (Kucharska, Twardzik 2007). Aktualnie do stacjonarnych punktów sprzedaży zaliczają się przede wszystkim: sklepy dyskontowe, domy towarowe, domy handlowe, supersamy, sklepy branżowe lub wielobranżowe, wszystkie sklepy specjalistyczne, stacje benzynowe, kioski oraz automaty, które zaliczają się do punktów sprzedaży drobnodetalicznej (Adamowicz, Zaręba 2015).

Popularną formą w handlu detalicznym jest handel obwoźny w którym rozwinięta jest sprzedaż z samochodów, systematycznie objeżdżających zaplanowane miejscowości. Taka sprzedaż odgrywa znaczącą rolę w zaopatrywaniu obszarów wiejskich lub letniskowych, w szczególności miejsc gdzie jest trudne i nieopłacalne utrzymywanie sklepów. Do handlu obwoźnego zalicza się również targowiska i bazary.

Szybko rozwijającą się formą handlu jest handel wysyłkowy tak zwany e-handel i e-commerce, czyli wirtualny lub elektroniczny. Do wymiany towarów dochodzi za pośrednictwem sieci internetowej. Domi- 
and the product is delivered via mail, courier, or by electronic means.

The role of retail trade in Poland increased in the post-1989 transition period. The aim was to create a market for consumer products and to reduce the dominance of economy based on manufacturing industry. The system transformation led to an abrupt increase in the consumption of food or nonfood products and services, which were becoming increasingly available. Retail trade began to play an important role in the system. Especially in large cities, the distribution sector offered consumers a wide variety of products available and an open but competitive market for manufacturers. Due to the investments of foreign and Polish companies, the developing trade contributed to the growth of consumption and intensification of competition while maintaining the required quality and low price level. The estimates show that foreign investments in the commercial sector in Poland have reached more than 50 billion USD. In addition to that, Polish capital investments are estimated at over 15 billion USD. Trade development contributes to the development of the entire economy. Investments in the distribution sector stimulated and boosted the economy, bringing investments in services and production, which had a great impact on the labour market and economic development. Nowadays, commerce along with services, generates around $17 \%$ of GDP and is, to some extent, the key to modernity. Owing to the strength and vitality of the distribution sector in the last two decades, new facilities have been built in Poland and the modernisation of the existing commercial and service facilities has taken place, which can also be seen as a contributing factor to changes in the model of day-to-day life (Faliński 2014).

The development of the distribution and retail trade sector within the market economy was manifested in the emergence of new, large-format retail facilities and withdrawal of small and medium-sized stores. Before 1990, supermarkets selling mainly groceries, as well as cooperative or state-owned department stores, were considered to be large-format retail facilities. These shops operated basing on a central management system (Wrzesińska 2008). At least 3 stages of development of the retail trade network within the market economy can be distinguished.

The first stage took place in the early 1990s. It was related to the privatisation and consolidation of retail chains after the collapse of the central planning economy system, which was the period of overall shortage of products. The strong demand for retail space in cities was partially met by the emergence of a number of small outlets, which were located in the outbuildings of tenement houses, and in blocks of flats from higher stories to basements (Kaczmarek, Szafrański 2007). The store of a Polish-Austrian brand Billa was the first western supermarket, which was opened in Warsaw in 1990. Globi was the pioneer of discount stores on the Polish market, while the first hypermarket was HIT, owned by a German nującą formą w e-handlu jest sklep internetowy, który prezentuje ofertę handlową na stronach www, gdzie umieszcza się opisy produktu, zdjęcia, prezentację multimedialną lub filmową oraz artykuły. Transakcja finalizowana jest drogą elektroniczną, a dostawa jest przeprowadzana za pośrednictwem poczty, kuriera lub również drogą elektroniczną.

Rola handlu detalicznego w Polsce wzrosła w okresie transformacji po 1989 r. Celem było wykreowanie rynku produktów konsumpcyjnych i zmniejszenie stopnia dominacji gospodarki opartej na przemyśle ciężkim. Transformacja systemowa przyczyniła się do nagłego zwiększenia konsumpcji coraz powszechniej dostępnych produktów żywnościowych, nieżywnościowych i usług. Handel zaczął pełnić ważną rolę systemową. Zwłaszcza $\mathrm{w}$ wielkich miastach sektor dystrybucyjny ofiarował konsumentowi obfitość oferty a producentowi otwarty lecz konkurencyjny rynek. Rozwijający się handel dzięki doinwestowaniu przez zagraniczne i polskie firmy przyczynił się do wzrostu konsumpcji, nasilenie konkurencji wszystkich ze wszystkimi przy zachowaniu wymaganej jakości i niskiego poziomu cen. Z szacunków wynika, że zagraniczne inwestycje w sektor handlowy w Polsce wyniosły ponad 50 miliardów dolarów. Do tego dochodzą inwestycje kapitału polskiego, które szacuje się na ponad 15 mld dolarów. Rozwój handlu przyczynia się do rozwoju całej gospodarki. Inwestycje sektora dystrybucji stymulowały i pobudzały gospodarkę, pociągając za sobą inwestycję w usługi, produkcję, co miało olbrzymie znaczenie dla rynku pracy oraz rozwoju gospodarczego. Współcześnie wraz z usługami handel wytwarza około $17 \%$ PKB i w pewnym stopniu stanowi klucz do nowoczesności. Dzięki sile i żywotności sektora dystrybucji w ostatnich dwóch dekadach w Polsce powstały nowe obiekty, zostały przeprowadzone modernizacje istniejących obiektów handlowych i usługowych, co można traktować również jako czynnik, który przyczynił się do zmiany modelu codziennego życia (Faliński 2014).

Rozwój sektora dystrybucji i handlu detalicznego w ramach gospodarki rynkowej ujawnił się powstaniem nowych, wielkopowierzchniowych obiektów handlowych oraz wycofywaniem sklepów małych i średnich. Za sklepy wielkopowierzchniowe przed rokiem 1990 uznawano supersamy oraz spółdzielcze i państwowe domy towarowe. Te sklepy funkcjonowały w oparciu o system centralnego zarządzania (Wrzesińska 2008). Można wyróżnić co najmniej 3 etapy rozwoju sieci handlu detalicznego $w$ ramach gospodarki rynkowej.

Pierwszy etap przebiegał na początku lat $90 \mathrm{XX}$ w. Był on związany z prywatyzacją i konsolidacją sieci handlowych po upadku systemu centralnego planowania, kiedy panował okres niedoborów. Silne zapotrzebowanie na przestrzeń handlową w miastach było uzupełniane poprzez powstające licznie małe placówki, które były lokalizowane w oficynach kamienic, na piętrach, parterach oraz w piwnicach bloków mieszkalnych (Kaczmarek, Szafrański 2007). Sklep polsko-austriackiej firmy Billa był pierwszym zachodnim supermarketem, który powstał w Warszawie w 1990 roku. Prekursorem dyskontowych sklepów na rynku 
brand Dohle, which started its operations in Poland in 1993 (Wrzesińska 2008).

The second stage took place in the last five years of the twentieth century. During this period, the network of small retail outlets was gradually supplemented with modern shopping facilities. The biggest Polish cities became location sites of supermarkets, hypermarkets and discount stores. Investors in the retail sector were mostly companies from Germany and France, as well as Portugal, the Netherlands, Austria and the United Kingdom. Till 2005 the first 20 commercial investors launched 1466 discount stores, 263 hypermarkets and 1270 supermarkets in Poland. The participation of these establishments in food product trade was estimated at 50\% (Kaczmarek, Szafrański 2007). In 1995, the first shopping centre in Poland was opened in Janki near Warsaw (Wrzesińska 2008).

The third stage began at the beginning of the 21st century and was characterized by the emergence of modern shopping malls with the floor area of over 10 thousand $\mathrm{m}^{2}$, in which the large-format retail trade was connected with a wide range of services, catering, entertainment and cultural services (Kaczmarek, Szafrański 2007). In 2015, there were 481 shopping centres in Poland with a total area exceeding 11 million $\mathrm{m}^{2}$ (PRCH RETAIL RESEARCH FORUM 2015). The development of modern largeformat retail stores in Poland was very rapid, even in comparison with Western European countries, which underwent a similar process of expansion at the turn of 70's and 80's. It took 6-7 years to open around 150 hypermarkets in Poland. In comparison, in Spain it took 20 years (Wrzesińska 2008).

In the initial period of transition in Poland, a significant decline in the number of regular and specialty department stores was recorded. This trend reversed in 1998, when this sector attracted the interest of foreign investors, who became the owners of more than one third of these facilities. A growing number of premium-priced branded items was added to the commercial offer, mainly for higher-income consumers. Department and speciality department stores, as well as large supermarkets selling mainly groceries grew faster than hypermarkets and supermarkets. Nowadays, the number of the other types of large facilities, such as department stores and department houses, is systematically decreasing. Department stores try to return to their classic wide range of assortment and high quality services, while specialty department stores narrow it to a more specified offer of a particular industry. In the years 1999-2015, the average retail area of hypermarkets decreased from over $8,000 \mathrm{~m} 2$ to slightly over $6,000 \mathrm{~m}^{2}$. This is due to the expansion of this form of trade in medium-sized cities, not only in large agglomerations. The average retail area in supermarkets has increased from almost $700 \mathrm{~m}^{2}$ to over $800 \mathrm{~m}^{2}$. Department stores and specialty department stores are characterized by the size of retail space unchanged over the years. Poland is an example of a country where internationalisation of polskim była sieć Globi, natomiast pierwszym hipermarketem był HIT, należący do niemieckiego Dohle, który rozpoczął działalność w Polsce 1993 roku (Wrzesińska 2008).

Drugi etap miał miejsce w ostatnim pięcioleciu XX w. W tym okresie sieć małych placówek handlowych zaczęto stopniowo uzupełniać nowoczesnymi obiektami handlowymi. Miejscem lokowania supermarketów, hipermarketów oraz dyskontów stały się największe polskie miasta. Inwestorami w sektorze handlu były koncerny przeważnie z Niemiec i Francji, a także Portugalii, Holandii, Austrii i Wielkiej Brytanii. Pierwszych dwudziestu inwestorów handlowych do roku 2005 uruchomiło w Polsce 1466 sklepów dyskontowych, 263 hipermarketów, oraz 1270 supermarketów. Łączny udział tych placówek w handlu produktami spożywczymi szacowany był na 50\% (Kaczmarek, Szafrański 2007). W roku 1995 w Polsce powstało pierwsze centrum handlowe w Jankach koło Warszawy (Wrzesińska 2008).

Trzeci etap rozpoczął się na początku XXI wieku i wyróżniał się lokalizacją nowoczesnych centrów handlowo-usługowych (shopping mall), o powierzchni powyżej 10 tys. $\mathrm{m}^{2}$, w których handel wielkopowierzchniowy powiązany został z szeroką ofertą usługową, gastronomiczną, rozrywkową i kulturalną (Kaczmarek, Szafrański 2007). W 2015 r. istniało w Polsce 481 centrów handlowych o łącznej powierzchni przekraczającej $11 \mathrm{mln}^{2} \mathrm{~m}^{2}$ (PRCH RETAIL RESEARCH FORUM 2015). Rozwój wielkopowierzchniowych nowoczesnych sklepów w Polsce był bardzo szybki nawet w porównaniu do krajów Europy Zachodniej, które przechodziły taki proces ekspansji na przełomie lat 70-80. Stworzenie około 150 hipermarketów w Polsce trwało 6-7 lat, a dla porównania w Hiszpanii 20 lat (Wrzesińska 2008).

W początkowym okresie transformacji Polska notowała znaczny spadek liczby domów handlowych i towarowych. W roku 1998 trend ten się odwrócił gdy tym sektorem zainteresowali się inwestorzy zagraniczni, którzy stali się właścicielami więcej niż jednej trzeciej części tych obiektów. W skład oferty towarowej coraz częściej wchodziły artykuły markowe o wygórowanych cenach, które przeznaczono głównie dla konsumentów o wyższych dochodach. Domy handlowe i towarowe, również supersamy rozwijały się szybciej niż hipermarkety i supermarkety. Teraz systematycznie zmniejsza się liczba pozostałych typów dużych obiektów czyli domów towarowych i handlowych. Domy towarowe próbują powrócić do swojej klasycznej szerokiej oferty asortymentowej i wysokiego poziomu usług, natomiast domy handlowe zawężają pogłębioną ofertę handlową w określonej branży. W latach 1999-2015 średnia powierzchnia sprzedażowa hipermarketów zmniejszyła się z ponad 8 tysięcy do nieco ponad 6 tysięcy $\mathrm{m}^{2}$. Wynika to $\mathrm{z}$ ekspansji tej formy handlu w miastach średniej wielkości, a nie tylko w dużych aglomeracjach. Średnia powierzchnia handlowa w supermarketach wzrosła natomiast z niecałych 700 do ponad $800 \mathrm{~m}^{2}$. Domy towarowe i handlowe charakteryzuja sie niezmienna na przestrzeni lat powierzchnią sprzedaży. Polska jest krajem, w którym internacjonalizacja handlu przebiega niezwykle 
trade is extremely dynamic, which is boosted by the still receptive internal market.

The dynamic development of foreign investments in trade market resulted in almost complete monopoly of foreign operators managing the hypermarket segment and their dominance in the segment of discount stores and supermarkets. Among the network companies operated by domestic capital, there are also supermarkets of the PSS "Społem" and other new organisations. The majority of these outlets operate on a franchise basis, where the form of discount stores is the most common. The rapid development of foreign networks triggered the privatisation process, contributed to the activation of Polish entrepreneurs, and encouraged imitative tendencies among the domestic capital in the trade market (Adamowicz and Zaręba 2015). When comparing the retail turnover of domestic chains of shops with foreign ones, the calculation where the criterion is the value of sales per an area unit clearly shows that the shop chains owned by Polish enterprises have higher economic efficiency.

Since 2004, there has been a noticeable change in location trends and in the size of shop floor area. Compared to the 1990s, there are more shops with less floor area and, as a rule, they are opened in smaller towns than before. In the initial expansion phase, an average hypermarket covered an area of about 9,000 $\mathrm{m}^{2}$, while in 2006 it decreased to 7,000 $\mathrm{m}^{2}$. In order to compete, develop and strengthen their position on the market, retail chains are trying to expand their influence by changing their operational format whereby hypermarkets are transformed into supermarkets and supermarkets into discount stores. They also often resolve to conduct mergers and acquisitions.

Shopping centres are the youngest form of the Polish distribution market. Usually, they used to be built away from the city centres, but currently all major cities possess such facilities nationwide. There is still a demand for this type of establishments, especially in smaller towns (Wrzesińska 2008).

The economic crisis which emerged in Europe in 2008 was milder in Poland than in other EU member states. One of the reasons was a thriving domestic trade characterised by high creativity and innovation, which attracts investments in support services, infrastructure and industrial production. It alleviated the effects of the global crisis in Poland. In the years 2008-2012, in our country trade was the second largest sector after heavy industry, whose share in GDP was between 16.7 and $17.1 \%$, which means that it was higher than the average in the EU countries. During the crisis, trade achieved a higher rate of growth than the manufacturing industry sector. In spite of the dynamic development of largeformat retail facilities, domestic trade in Poland has a very fragmented structure of operating entities. Medium and large enterprises are owned by foreign entities, while the domestic sector is composed predominantly of micro-enterprises (KłosiewiczGórecka 2014). dynamicznie, czemu sprzyja nadal chłonny rynek wewnętrzny.

W wyniku dynamicznie rozwijających się inwestycji zagranicznych w handlu ukształtował się niemal całkowity monopol operatorów zagranicznych obsługujących segment hipermarketów oraz ich dominacja w segmencie sklepów dyskontowych i supermarketów. Wśród przedsiębiorstw sieci będącej w dyspozycji kapitału krajowego, są również supermarkety PSS „Społem” i innych nowych organizacji. Większość tych punktów działa na zasadach franczyzowych, dominuje tu forma sklepów o profilu dyskontowym. Szybki rozwój sieci zagranicznych wymusił procesy prywatyzacyjne, przyczynił się do aktywizacji przedsiębiorczości pośród polskich przedsiębiorców i uaktywnił odruchy naśladowcze dla rodzimego kapitału znajdującego się w handlu (Adamowicz i Zaręba 2015). Przy porównaniu obrotów detalicznych sieci krajowych z zagranicznymi, w obliczeniach, gdzie kryterium jest wartość sprzedaży w przeliczeniu na jednostkę powierzchni wynika, iż większą efektywnością ekonomiczną cechują się sieci stanowiące własność polskich przedsiębiorstw.

Od roku 2004 zauważalna jest zmiana w tendencjach lokalizacyjnych oraz wielkości powierzchni sklepów. W porównaniu do lat 90ych powstaje więcej sklepów o mniejszej powierzchni, a obiekty takie powstają często w coraz mniejszych miastach. Przeciętna powierzchnia hipermarketu w początkowej fazie ekspansji wynosiła około 9 tys. $\mathrm{m}^{2}$, natomiast w 2006 roku zmniejszyła się do 7 tys. $\mathrm{m}^{2}$. Aby konkurować, rozwijać się i umacniać na rynku, sieci starają się poszerzać swoje wpływy przez co zmieniają formaty działalności poprzez zamianę hipermarketów na supermarkety a supermarketów na dyskonty, podejmują też często decyzje w sprawie fuzji i przejęć.

Najmłodszą formą na polskim rynku dystrybucji są centra handlowe, które były budowane zazwyczaj w pewnej odległości od śródmieść dużych miast, obecnie wszystkie ważniejsze miasta w kraju posiadają takie obiekty. Nadal jednak istnieje zapotrzebowanie na tego typu placówki zwłaszcza w mniejszych miastach (Wrzesińska 2008).

Kryzys gospodarczy, który w Europie ujawnił się w 2008 roku, w Polsce przebiegał łagodniej niż w innych państwach członkowskich UE. Jedną z przyczyn był prężnie rozwijający się handel wewnętrzny, który cechuje się wysoką kreatywnością i innowacyjnością, co pociąga za sobą inwestycje w towarzyszących usługach, infrastrukturze i produkcji przemysłowej. Łagodziło to skutki światowego kryzysu w naszym kraju. W latach 2008-2012 handel w naszym kraju był drugim po przemyśle sektorem gospodarki, którego udział w PKB kształtował się w przedziale między 16,7 a $17,1 \%$ co oznacza, że był wyższy niż średnio w krajach Unii Europejskiej. W czasie kryzysu handel notował wyższą dynamikę wzrostu od sektora przemysłu. Mimo dynamicznego rozwoju wielkopowierzchniowych obiektów handlowych handel wewnętrzny w Polsce posiada bardzo rozdrobnione struktury podmiotowe, Do zagranicznych podmiotów należą średnie i duże przedsiębiorstwa, natomiast w skład krajowego sektora wchodzą w dominującej części mikrofirmy (Kłosiewicz-Górecka 2014). 


\section{Functions of large-format retail trade}

The primary function of trade is to change the size and structure of the commodity flow between the sphere of production and the sphere of consumption. The initial form of this flow is shaped by the manufacturers, which means that it is characterised by large batches of deliveries and often narrow assortments. The final form of the commodity flow is adjusted to the personal preferences of customers looking for an offer that satisfies their demands by purchasing a small quantity of goods. The task of trade is to limit and mitigate the emerging divergences (generic, spatial, temporal, concerning the assortment and quantity) between the initial and the final arrangement of goods (Kucharska, Twardzik 2007). The basic functions are: creating a heterogeneous structure of the offer, managing the handling of goods over time, concentrating the production which is territorially dispersed, forming single batches of goods, shaping the assortment structures of goods etc. (Szczepankiewicz 2011).

Therefore, the main function of trade is to create a diversified structure of the commodity offer for buyers, with the initial form of the offer significantly changed in comparison with the final one. The task of trade is to adjust the supply offers to the demand occurring on the market. The production sphere can be influenced by informing manufacturers about which goods are in demand on the buyers' side. Trade also affects the sphere of consumption by encouraging customers to buy goods that are offered by manufacturers or by informing them of the offered product range (Kucharska, Twardzik 2007).

Coordinating the turnover of commodities over time results, among others, from the difference created by the duration of time that has passed between production and consumption. The existence of trade is fully justified by the spatial differences: in many cases, there is a huge difference between the place of production and the place of usage. Trade is responsible for concentrating in one place the goods whose production is dispersed and distributes certain goods to places where they are in demand (Pilarczyk, Sławińska, Mruk 2001).

The task of trade is to form single batches of goods, which results from the discrepancy between the size of a delivery batch and the quantity of goods that a buyer wants to purchase. One important task of trade is to minimise the quantitative difference which occurs between the manufacturers' offer and the demand reported by the buyers.

It is through trade that an appropriate selection is made and an assortment structure is built in order to meet buyers' expectations. Goods, when passing from the sphere of production to the sphere of transactions, are classified according to the industry they belong to. The kind of demands they satisfy is, at the moment of sale, a decisive factor determining this classification. The basic criteria that influence the formation of commercial assortment are the needs along with the complementarity and

\section{Funkcje handlu wielkopowierzchniowego}

Podstawową funkcją handlu jest zmiana rozmiaru i struktury masy towarowej między sferą produkcji i sferą konsumpcji. Układ masy początkowej jest kształtowany dzięki producentom, oznacza to, iż charakteryzuje się dużymi partiami dostaw i często wąskim asortymentem. Układ masy końcowej zostaje dostosowany do osobistych preferencji odbiorców oczekujących na ofertę, która zaspakaja ich potrzeby poprzez nabycie produktów w małej ilości. Zadaniem handlu jest ograniczanie i łagodzenie powstających rozbieżności, rodzajowych, przestrzennych, czasowych, asortymentowych i ilościowych pomiędzy początkowym i końcowym układem dóbr (Kucharska, Twardzik 2007). Można wyróżnić takie funkcje podstawowe jak: kreowanie różnorodnej struktury oferty, kierowanie obrotem towarów w czasie, skupianie produkcji, która jest terytorialnie rozproszona, formowanie pojedynczych partii towarów, modelowanie struktur asortymentowych towarów i in. (Szczepankiewicz 2011).

Główną funkcją handlu jest więc kreowanie zróżnicowanej struktury oferty towarowej dla nabywców, która różniła się znacznie w układzie początkowym oraz końcowym. Handel ma za zadanie dopasować oferty podażowe do ujawnionego na rynku popytu. $\mathrm{Na}$ sferę produkcji można oddziaływać dzięki informowaniu producentów o tym na jakie dobra jest zapotrzebowanie przez nabywców. Handel ma również wpływ na sferę spożycia dzięki pobudzeniu klientów do zakupu dóbr, które są oferowane przez producentów lub dzięki informowaniu o danej ofercie asortymentowej (Kucharska, Twardzik 2007).

Koordynowanie obrotem towarów w czasie wynika m.in. z rozbieżności, która powstaje pomiędzy czasem od wyprodukowania do konsumpcji. Istnienie handlu jest w pełni uzasadnione poprzez różnice przestrzenne, występuje w wielu przypadkach ogromna różnica między miejscem produkcji, a użytkowania. Handel jest odpowiedzialny za koncentrowanie w jednym punkcie towarów, których wytwarzanie jest terytorialnie rozproszone i zajmuje się dystrybucją danego dobra do miejsc w których występuje na nie zapotrzebowanie (Pilarczyk, Sławińska, Mruk 2001).

Zadaniem handlu jest formowanie pojedynczych partii towarów, co wynika z braku zgodności między wielkością partii dostawy, a preferowaną przez nabywców partią zakupu. Ważnym zadaniem handlu jest odpowiednie wyrównanie różnicy ilościowej, która występuje między ofertą producentów, a zapotrzebowaniem zgłaszanym przez nabywców.

Przez handel dokonuje się również odpowiedni dobór i kształtowana jest struktura asortymentowa tak aby oferta spełniała oczekiwania nabywców. Produkty przechodzac ze sfery produkcyjnej do sfery, w której dokonuje się obrót, klasyfikowane są według gałęzi przemysłu. W chwili sprzedaży decydujący wpływ na ich uporządkowanie ma rodzaj zaspokajanych potrzeb. Podstawowym kryterium, które ma wpływ na kształtowanie asortymentu handlowego są potrzeby oraz komplementarność i substytucyjność produktów. Głównym celem handlu detalicznego jest więc 
substitutability of products. The main purpose of retail trade is to meet the needs and preferences of consumers by adjusting the product offer to the assortment as well as the quantity to individual needs, but also to create appropriate purchasing conditions that will save time and effort (Kucharska 2010).

Other functions of retail trade are:

- Organising an efficient physical flow of products from, usually, a limited number of manufacturing companies to all points of sale, which are often dispersed over a large area.

- Providing a wide range of products that belong to one or more different categories, which makes the choice easier for buyers.

- Creating an appropriate product offer with regard to quality and quantity.

- Skilful management of the flow of goods in space and over time, using appropriate indices of stock inventory and commodity turnover.

- Taking the risk associated with transferring ownership and payments from the buyer to the manufacturer.

- Creating an appropriate atmosphere in retail outlets and providing adequate after-sales services.

- Providing comprehensive information and advice as well as maintaining other ways of communication with the market (Kucharska, Twardzik 2007).

The following functions may be distinguished on the basis of activities performed in retail trade:

Sales function - which includes; specification of the range of goods (assortment), the time (shop working hours) and the place (appropriate store location) in which they are offered to customers. The display of the goods, demonstration of their advantages and provision of competent customer service are carried out as part of this function.

Purchase function - includes the selection of appropriate suppliers of particular goods which are put on sale at a particular retail establishment, specifying the order placement date with the supplier as well as the size of the batch of goods which is ordered, arranging the terms and conditions of the transaction, signing purchase agreements, organising the delivery of goods to a retail establishment;

The function of maintaining appropriate inventory - includes receipt of appropriate deliveries of goods, their placement in merchandise niches of assortment stocks, held in the sales room and in in-store magazines of a given retail establishment, good safeguarding the goods against theft or destructive damage, preparation of all goods for sale and precautions against creating a surplus of goods which are unnecessary at a given time;

The above-mentioned functions can apply to both small retail outlets and large businesses that can be composed of tens or hundreds of outlets. The essence of the function remains the same all the time, only the scale and manner of implementation may change. Of the trade functions discussed above sprostanie potrzebom i preferencjom konsumentów poprzez dostosowanie oferty towarowej co do asortymentu jak również wielkości do ich indywidualnego zapotrzebowania, ale też wykreowanie odpowiednich warunków zakupu, które zaoszczędzą czas jak i wysiłek (Kucharska 2010).

Można wyodrębnić również inne funkcje handlu detalicznego takie jak:

- Organizowanie sprawnego fizycznego przepływu produktów z przeważnie ograniczonej ilości przedsiębiorstw wytwórczych do wszystkich punktów sprzedaży często rozrzuconych na dużym obszarze,

- Zapewnianie bogatej oferty produktów, które należą do jednej lub kilku różnych kategorii towarów, co ułatwia dokonywanie wyboru kupującym,

- Kreowanie odpowiedniej oferty towarowej co do jakości oraz ilości,

- Umiejętne kierowanie strumieniami przepływu towarów w przestrzeni i w czasie przy wykorzystaniu odpowiednich wskaźników zapasów magazynowych i rotacji towarów,

- Ponoszenie ryzyka związanego z przekazywaniem tytułu własności i transferem opłat w drodze od nabywcy do producenta,

- Kreowanie odpowiedniej atmosfery w placówkach handlowych i świadczenie odpowiednich usług posprzedażowych,

- Udzielanie kompleksowej informacji oraz doradztwo, a także prowadzenie innych sposobów komunikowania się z rynkiem (Kucharska, Twardzik 2007).

Na podstawie czynności realizowanych w handlu detalicznym możemy wyodrębnić następujące funkcje:

Funkcję sprzedaży - w której zawiera się określanie, jak duży wachlarz towarów (asortyment), kiedy (czas pracy sklepu) oraz gdzie (odpowiednia lokalizacja sklepu) będzie zaoferowany klientom. W ramach tej funkcji organizowana jest ekspozycja towarów, demonstrowane są ich zalety i dokonywana kompetentna obsługa klientów.

Funkcję zakupu - obejmującą wybór odpowiednich dostawców poszczególnych towarów, które są wystawiane na sprzedaż w konkretnej placówce handlowej, określenie daty składania zamówienia u dostawcy jak i również wielkości partii towaru, która jest zamawiana, uzgadnianie z dostawcą warunków transakcji, podpisywanie umów zakupu, organizację planowych dostaw towarów do placówki handlowej;

Funkcję utrzymywania odpowiednich zapasów - obejmującą przyjmowanie odpowiednich dostaw towarów, rozmieszczanie w niszach towarowych zapasów asortymentu, będących na sali sprzedażowej i w magazynach sklepowych danej placówki handlowej, dobre zabezpieczenie towarów przed kradzieżą bądź zniszczeniem, przygotowanie wszystkich towarów do sprzedaży i dbałość o to, aby nie powstawał duży nadkład towarów, które nie są niezbędne w danej chwili;

Wymienione wyżej funkcje mogą się odnosić zarówno do jednego małego punktu sprzedaży deta- 
we distinguish the following tasks of retail trade (Szulce et al. 2008):

- Collecting a variety of goods that come from many sources in one place,

- Offering goods in such a way that all interested buyers have the easiest possible access to them.

- Constant replenishment of the stock of goods which are on offer, so that there is no shortage of a given commodity; the products should be always available to each interested customer.

- Selling goods in quantities which are most readily purchased for current consumption according to the requirements and needs of each consumer

The efficient execution of the specified functions enables commercial enterprises to achieve competitive advantage on the market. In order to achieve such an advantage, one may apply any of the selected strategies of operation such as the cost cutting strategy, diversification strategy, competition avoidance strategy and strategy of cooperation or concentration (Kucharska, Twardzik 2007). Choosing the best strategy of operation has to be adapted to an appropriate organisational form of retail trade.

\section{Conditions of development and location of large- format retail trade in the city of Biała Podlaska}

The city of Biała Podlaska is located in the eastern part of Poland, more precisely in the northern part of Lublin voivodeship, and is the second largest city in southern Podlachia. Thanks to its location, it is an important cultural and economic centre in the region. It is located on an important European transport route where the national road number 2 lies, being part of the Berlin-Moscow connection, and also the main railway line of Berlin-Moscow service goes through the city. The convenient, albeit peripheral, location creates many opportunities for the development of the city and the region.

The city of Biała Podlaska does not have preserved continuity in the public space, it is divided into two parts: the downtown or the city centre and the southern part. The zones are not interconnected, but for the inhabitants of the city both of them are important in satisfying consumer, educational and cultural needs. The central part of the city, i.e. the downtown, will include: Plac (square) Wolności, Park Radziwiłł, ulica (street) Brzeska, Plac Wojska Polskiego and Plac Szkolny Dwór, while the southern part includes: Plac Trzech Krzyży, the part of the Krzna River Valley with the park, Park Zofii Las and the square in front of the railway station and partly revitalized post-industrial areas. Prior to 1989, this part of the city housed an industrial district which systematically changes its appearance and functions.

Biała Podlaska is the fourth largest city in terms of population in Lublin voivodeship, behind cities such licznej, jak i dla dużego przedsiębiorstwa, które może liczyć dziesiątki czy setki punktów sprzedaży. Istota funkcji jest cały czas taka sama, zmienia się jedynie skala i sposób realizacji. Z omówionych wyżej funkcji handlu wyróżniamy następujące zadania handlu detalicznego (Szulce i in. 2008):

- Zbieranie w jednym miejscu przeróżnych towarów, które pochodzą z wielu źródeł,

- Oferowanie dóbr w taki sposób, aby wszyscy zainteresowani nabywcy mieli jak najłatwiejszy do nich dostęp.

- Ciagge uzupełnianie zapasu towarów, które sa w ofercie, aby nie zdarzyła się sytuacja, w której będzie brakowało danego dobra, produkty powinny być zawsze dostępne dla każdego zainteresowanego klienta.

- Sprzedawanie towarów w takich ilościach, które są najchętniej nabywane do bieżącej konsumpcji, według wymagań i potrzeb każdego konsumenta

Sprawna realizacja wyszczególnionych funkcji pozwala przedsiębiorstwom handlowym osiągnąć przewagę konkurencyjną na rynku. W celu osiągnięcia takiej przewagi może być zastosowana jedna z wybranych strategii działania, takich jak stratega: cięcia kosztów, strategia zróżnicowania, strategia unikania konkurencji oraz strategia kooperacji lub koncentracji (Kucharska, Twardzik 2007). Wybór najlepszej strategii działania, trzeba dostosować do odpowiedniej formy organizacyjnej w handlu detalicznym.

\section{Uwarunkowania rozwoju i lokalizacji handlu wiel- kopowierzchniowego w mieście Biała Podlaska}

Miasto Biała Podlaska jest położone we wschodniej części Polski, a dokładniej w północnej części województwa lubelskiego i stanowi drugie w stosunku do wielkości miasto na południowym Podlasiu. Dzięki swojemu położeniu jest to ważny ośrodek kulturowy oraz gospodarczy w regionie. Jest położone przy ważnym szlaku transportu europejskiego, gdzie znajduje się droga krajowa numer 2, która stanowi część połączenia Berlin - Moskwa, przez miasto przebiega też główna linia kolejowa relacji Berlin - Moskwa. Dogodne choć peryferyjne położenie stwarza wiele możliwości dla rozwoju miasta i regionu.

Miasto Biała Podlaska nie posiada zachowanej ciągłości w przestrzeni publicznej, jest podzielone na dwie części śródmiejską i południową. Strefy nie są wzajemnie powiązane, jednak dla mieszkańców miasta obie części są ważne przy zaspokajaniu potrzeb konsumpcyjnych, edukacyjnych i kulturowych. Do centralnej części czyli śródmieścia zaliczymy Pl. Wolności, Park Radziwiłłów, ul. Brzeską, Pl. Wojska Polskiego oraz Pl. Szkolny Dwór, natomiast do południowej należy Plac Trzech Krzyży, część doliny Krzny wraz z parkiem, Park Zofii Las oraz plac przed dworcem PKP oraz częściowo rewitalizowane obszary poprzemysłowe. Przed 1989 rokiem w tej części miasta mieściła się dzielnica przemysłowa, która systematycznie zmienia swoje oblicze i funkcje.

Biała Podlaska zajmuje 4 miejsce wśród miast pod względem liczby ludności w województwie lubelskim, wyprzedzają ją takie miasta jak Zamość, Chełm oraz 
as Zamość, Chełm and Lublin. Based on GUS (Eng. Central Statistical Office) data, the highest number of inhabitants in Biała Podlaska was recorded in 2001 (59325 inhabitants). In 2016, the population was decreased by about 2000 people compared to 2001 (GUS data).

The retail trade located in the city of Biała Podlaska not only serves the inhabitants of the city, but also residents of the neighbouring municipalities and cities as well as visitors from Belarus. The extent to which Biała Podlaska retailers influence customers can be divided into three geographical areas characterized by different access to the retail network located in the city (figure 1). The first area includes the city itself, but also Biała Podlaska municipality which has about 13000 inhabitants, and between $80 \%$ and $100 \%$ of the inhabitants of the town and the municipality use the shops located in Biała Podlaska. The other area is the municipalities and towns in the immediate vicinity of the first zone, which includes Piszczac (over 7000
Lublin. Opierając się na danych GUS największą liczbę mieszkańców w Białej Podlaskiej odnotowano w 2001 roku (59325 mieszkańców). W roku 2016 liczba ludności była mniejsza o około 2000 osób w porównaniu do roku 2001 (Dane GUS).

Handel detaliczny zlokalizowany w mieście Biała Podlaska obsługuje nie tylko mieszkańców miasta lecz także mieszkańców okolicznych gmin i miast a także przyjezdnych z Białorusi. Zasięg z jakim oddziałują na klientów sklepy z Białej Podlaskiej można podzielić na trzy obszary geograficzne, które charakteryzują się różnym dostępem do sieci handlowej zlokalizowanej w mieście (rysunek 1). Do pierwszego obszaru zalicza się same miasto, ale także gminę Biała Podlaska, która liczy około 13000 osób, a od 80\% do 100\% mieszkańców miasta jak i gminy korzysta ze sklepów położonych w mieście Biała Podlaska. Drugim obszarem są gminy oraz miasta w bezpośrednim położeniu ze strefą pierwszą, a zaliczają się do nich: gmina Piszczac (ponad 7000 osób), gmina Terespol (ponad 6 500), miasto Terespol (około 6000 osób), gmina Janów Podlaski

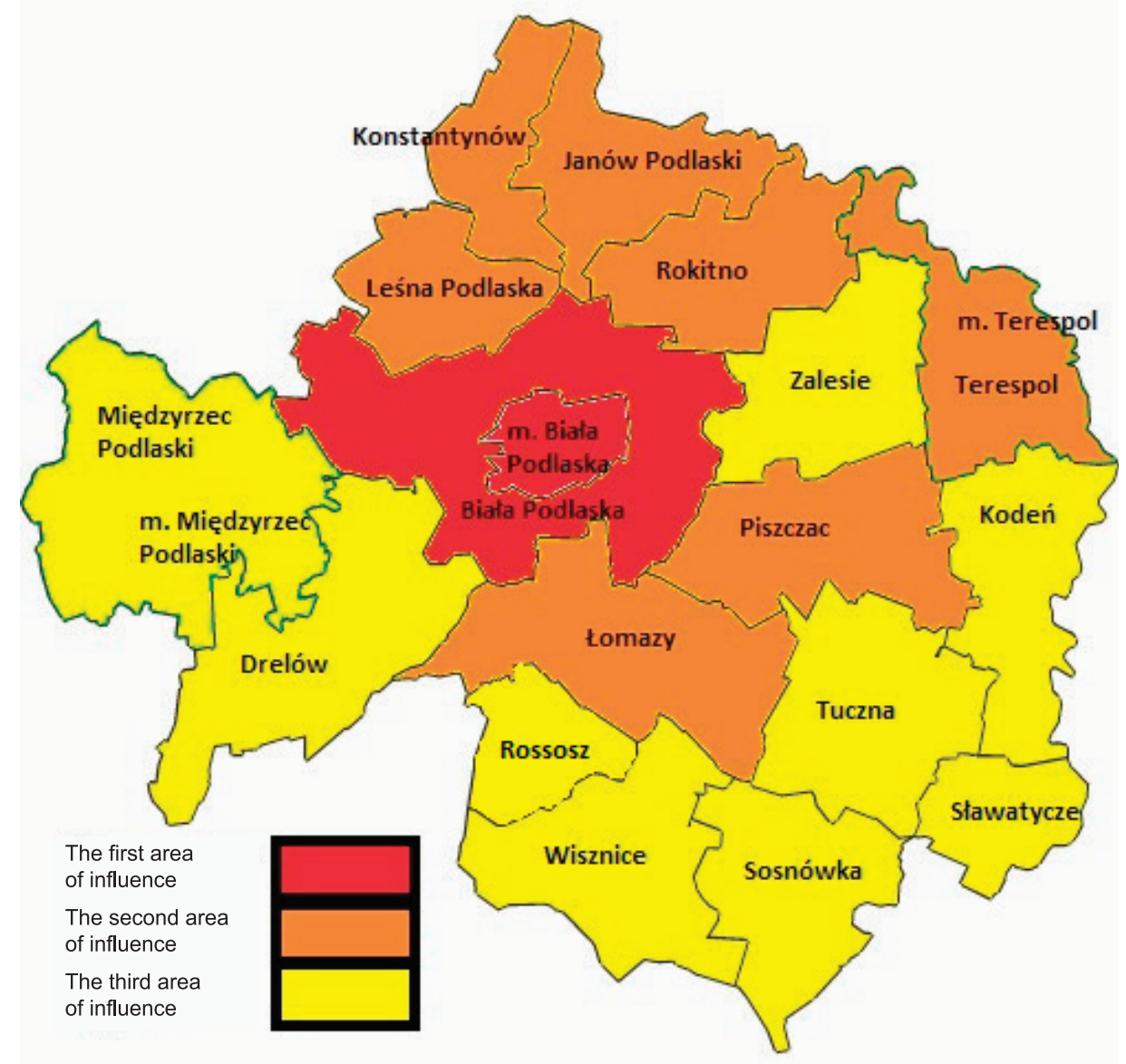

\section{Legend:}

The first area of influence/Pierwszy obszar wpływów The second area of influence/ Drugi obszar wpływów The third area of influence/ Trzeci obszar wpływów

Figure 1. Main geographic areas with the distribution of retail customers on the example of Biała Podlaska Rysunek 1. Główne obszary geograficzne rozmieszczenia klientów sklepów detalicznych na przykładzie miasta Biała Podlaska Source: own elaboration.

Źródło: Opracowanie własne. 
people), gmina (borough) Terespol (over 6500), the town of Terespol (about 6000 people), Janów Podlaski (over 5500), Łomazy (over 5000), Leśna Podlaska (about 4500), Konstantynów (more than 4000), Rokitno (over 3000), which makes a total of 41500 people. About $50-75 \%$ of the inhabitants in this area make frequent purchases in Biała Podlaska. The third area consists of municipalities and cities which lie at a considerable distance from the city of Biała Podlaska or have their own welldeveloped own commercial area. These include the town of Międzyrzec Podlaski (about 17000), gmina Międzyrzec Podlaski (about 10 000), Drelów (about 5500), Wisznice (about 5000), Zalesie (about 4500), Kodeń (about 3500), municipality of Tuczno (over 3000), municipality of Sosnówka (about 2500), municipality of Sławatycze (over 2000), which in total gives approximately 53000 people. Between 25 and $50 \%$ of the population in this area make frequent purchases in Biała Podlaska.

The retail trade of Biała Podlaska serves about 120000 people. In addition, there is a population that has not been included. It refers to people who regularly come from Belarus, and it is thanks to them there is still a great demand for modern retail space. Belarusians in the Polish border area usually buy items of consumer electronics, clothes and footwear, cosmetics and cleaning materials. On that basis, it is concluded that the purchases made by Belarusians are of consumptive nature (Powęska 2014). Shopping in Biała Podlaska is also done by buyers from neighbouring counties as well as by transit tourists.

Small retail outlets which offer mostly groceries and products for daily use are located within housing estates. Large-format retail establishments require a convenient location, which should be considered from the point of view of investors and buyers. Choosing the optimum location within the existing architectural layout is not always possible. Location is a key success factor for a retail company. Good location must also meet the expectations of residents and it cannot deteriorate the functioning conditions of other facilities and establishments. The role of the municipal authorities is to make appropriate localisation decisions for large-format retail establishments taking into account the existing conditions and possibilities of change when reconciling the interests of different parties with the welfare of the society. Even the most attractive and best chains, cannot achieve complete success if they decide to run their business in the wrong place (Sullivan, Adcoc 2003). Favourable or unfavourable location influences to a large extent the success or failure of a given retail outlet. It is estimated that about $85 \%$ of the sales of a given facility is determined by the location and external factors. The reason for such high importance of location lies in the nature of retail trade and the specific nature of its surroundings. The cornerstone of this commercial activity is traffic, i.e. continuous influx of potential buyers to a given trade establishment. With an advantageous location, there are good chances that (ponad 5 500.), gmina Łomazy (ponad 5000), gmina Leśna Podlaska (około 4 500), gmina Konstantynów (ponad 4 000), gmina Rokitno (ponad 3 000) co łącznie stanowi około 41500 osób. Z tego obszaru około 50 - 75\% mieszkańców dokonuje często zakupów na terenie miasta Biała Podlaska. Trzeci obszar stanowia gminy oraz miasta, które znajduja się już w znacznej odległości od miasta Biała Podlaska lub mają dobrze rozwiniętą własną powierzchnie handlową. Zalicza sie do nich: miasto Międzyrzec Podlaski (około 17 000), gmina Międzyrzec Podlaski (około 10 000), gmina Drelów (około 5 500), gmina Wisznice (około 5 000 ), gmina Zalesie (około 4500 ), gmina Kodeń (około 3 500), gmina Tuczna (ponad 3000 ), gmina Sosnówka (około 2 500), gmina Sławatycze (ponad 2000 ), co łącznie w przybliżeniu daje około 53000 osób. Na tym obszarze częste zakupy w Białej Podlaskiej dokonuje od 25 do 50\% mieszkańców.

Handel detaliczny Białej Podlaskiej obsługuje w tej liczbie około 120000 osób. Dodatkowo istnieje populacja, która nie została ujęta, chodzi tutaj o osoby systematycznie przyjeżdzające z Białorusi, to dzięki nim jest nadal duże zapotrzebowanie na nowoczesną przestrzeń handlową. Przyjezdni z Białorusi w polskiej strefie przygranicznej nabywają głównie artykuły radiowo-telewizyjne ubrania oraz obuwie, artykuły kosmetyczne wraz z środkami czystości, na taj podstawie można stwierdzić, że zakupy dokonywane przez Białorusinów mają charakter konsumpcyjny (Powęska 2014). Zakupów w Białej Podlaskiej dokonują także nabywcy z sąsiednich powiatów, a także turyści tranzytowi.

Małe placówki handlowe oferujące głównie produkty spożywcze i codziennego użytku lokalizowane są wewnątrz osiedli mieszkaniowych. Placówki wielkopowierzchniowe wymagają dogodnej lokalizacji, która należy rozpatrywać od strony inwestorów i od strony nabywców. Wybór optymalnej lokalizacji w ramach istniejącej zabudowy nie zawsze jest możliwy. Lokalizacja stanowi kluczowy czynnik sukcesu dla przedsiębiorstwa handlowego. Dobra lokalizacja musi spełniać także oczekiwania mieszkańców i nie może pogorszyć. warunków funkcjonowania innych obiektów i placówek. Rolą samorządu miasta jest podejmowanie odpowiednich decyzji lokalizacyjnych dla wielkopowierzchniowych obiektów

handlowych z uwzględnieniem istniejących uwarunkowań i możliwości zmian przy pogodzeniu interesów różnych stron i interesów społecznych. Nawet najbardziej atrakcyjne i najlepsze sieci jeśli zdecydują się na prowadzenie swojej działalności w złym miejscu nie mogą odnieść pełnego sukcesu (Sullivan, Adcoc 2003). Korzystna bądź niekorzystna lokalizacja wpływa w dużym stopniu na sukces lub porażkę danego punktu sprzedaży detalicznej. Szacuje się, że około $85 \%$ sprzedaży danego obiektu jest determinowane przez lokalizację i czynniki zewnętrzne. Przyczyna tak dużego znaczenia jakie jest przypisywane lokalizacji znajduje się $\mathrm{w}$ naturze handlu detalicznego oraz specyfiki jego otoczenia. Filarem tej działalności gospodarczej jest ruch, czyli ciągły napływ potencjalnych nabywców do danej placówki handlowej. Przy dobrej lokalizacji placówki, są duże szanse, iż potencjalni nabywcy właśnie do niej się 
prospective buyers will come to the outlet. If the location is too far away from one's place of residence or work, then customers will have less motivation to visit the store due to the extra cost of travel or having to devote more time for this purpose. The quality of transportation access is also of great importance. When the right investment location is chosen, success may follow on its own and if the location is poorly selected, then the economic performance of the establishment will be poor even if marketing activities are implemented. Once a specific location has been chosen, the facility will function there for a long time, i.e. it will be assigned to a specific place in space. The only change that will be possible to implement is to re-brand or change the assortment offer. An important element in choosing the right location is the development and functionality of the site. This constitutes a long-term and lasting impact factor for the results obtained by shops specialising in large-format retail trade (Sławińska 1989). It must also be taken into account that the choice of location may be influenced by factors not related to trade and one should be aware of the policy of optimising the functioning of a given region at various levels, which may influence the strategy and development of a given facility. Decisions regarding the choice of location for investment are made in two phases. The first one is to determine the overall location resulting from the accepted expectations and the size of the demand for sales space at a given location. The second phase specifies the choice of a specific place - a detailed location. Some investors skip the first phase and analyse only the second phase.

The first phase begins with the indication of the market space where the facility will receive buyers and serve them. An investor looks for an area that will enable them to achieve a high turnover and will allow for maintaining a high markup with respect to the customs of the area; they also take into consideration the occurrence of the competition, the behaviour and habits of customers, as well as the decisions taken by the authorities at different levels that have an impact on sustainable development. The choice of a general location depends primarily on the number of the population and on the demand for a given product offered by the investor.

The second phase is a detailed location, which is linked to the spatial trading structure. In this phase, it is necessary to learn what the permitted type of building is, what streets are there, what districts of the city are in the vicinity and what is their economic and social function, etc. Factors that contribute to designating a specific location are constantly changing, which is caused by the lack of sales space in city centres, which leads to a growing tendency among the population to make large purchases at greater intervals. For this reason, large-format retail facilities which offer basic products for daily use are built even in medium-sized cities. The favourable location of those establishments and the access to parking lots make shopping easier. The development of new suburban areas is progressing alongside the development of urban space and the emergence of udadzą, jeśli lokalizacja będzie zbyt odległa od miejsca zamieszkania czy pracy to klienci będą mieli słabszą motywację, aby odwiedzać ten sklep ze względu na dodatkowe koszty dojazdu czy poświęcenia większej ilości czasu. Duże znaczenie ma również jakość połączenia komunikacyjnego. Przy wybraniu odpowiedniej lokalizacji inwestycji sukces może przyjść sam, natomiast jeśli lokalizacja zostanie źle wybrana, to wyniki ekonomiczne placówki będą słabe nawet przy prowadzeniu działań marketingowych. Decydując się raz na określoną lokalizację placówka już przez długi okres będzie w niej funkcjonowała, czyli zostanie przypisana do określonego miejsca w przestrzeni, jedyną zmianą jaka będzie możliwa do realizacji to przebranżowienie lub zmiana oferty asortymentowej. Istotnym elementem przy doborze odpowiedniej lokalizacji jest zagospodarowanie i funkcjonalność powierzchni. Stanowi to długookresowy i trwały czynnik oddziaływania na uzyskiwane wyniki przez sklepy specjalizujące się w handlu wielkopowierzchniowym (Sławińska 1989). Trzeba również brać pod uwagę to iż na dokonanie wyboru lokalizacji mogą mieć wpływ czynniki niezwiązane $\mathrm{z}$ handlem, należy też liczyć się z polityką optymalizacji funkcjonowania danego regionu na różnych szczeblach, która może mieć wpływ na strategie i rozwój danego obiektu. Decyzje odnośnie wyboru lokalizacji pod inwestycję podejmowane są w dwóch fazach, pierwsza ma za zadanie wyznaczyć ogólną lokalizację wynikającą z przyjętych oczekiwań i rozmiaru zapotrzebowania na powierzchnię sprzedażową w danej lokalizacji. W fazie drugiej precyzuje się wybór konkretnego miejsca - lokalizację szczegółową. Niektórzy inwestorzy pomijają fazę pierwszą i analizują jedynie fazę drugą.

Faza pierwsza rozpoczyna się od wskazania przestrzeni rynkowej, gdzie dana placówka przyjmie i będzie obsługiwała nabywców. Inwestor poszukuje takiego obszaru, który będzie umożliwiał osiąganie wysokich obrotów oraz pozwoli mu utrzymywać marżę na wysokim poziomie uwzględniając, obyczaje panujące na danym obszarze, występowanie konkurencji, zachowania oraz przyzwyczajenia klientów, ale również decyzje podjęte przez władze znajdujące się na różnych szczeblach, które mają wpływ na zrównoważone zagospodarowanie. Wybór lokalizacji ogólnej zależy przede wszystkim od ilości ludności oraz od tego jakie jest jej zapotrzebowanie na daną ofertę produktową, którą posiada inwestor.

Drugą fazą jest lokalizacja szczegółowa, która jest powiązana z przestrzenną strukturą handlową. W tej fazie trzeba się zapoznać z tym jaki jest dozwolony rodzaj zabudowy, jakie występują ciągi ulic, jakie są w pobliżu dzielnice miasta, oraz jaka jest ich funkcja gospodarczo-społeczna itp. Czynniki, które przyczyniają się do wyznaczania lokalizacji szczegółowej ciągle ulegają zmianom, przyczynia się do tego niewydolność śródmieść w powierzchnię sprzedażową, co przekłada się na rosnącą wśród ludności skłonność do robienia dużych zakupów w większych odstępach czasowych. Dlatego nawet w średniej wielkości miastach powstają wielkopowierzchniowe obiekty handlowe, które w ofercie mają podstawowe artykuły zaspakajające codzienne potrzeby. Ułatwieniem w dokonywaniu zakupów w tych placówkach jest ich dogodne położe- 
new housing estates, which further encourages investors to place their investments outside the downtown area (Szulce 1998).

\section{Structure of the retail network in the city and its location}

There are five shopping centres in Biała Podlaska; three of them are located in the city centre and two of them are in the southern part of the city (figure 2). Atrium, Drop and Rywal shopping centres are located in the city centre, whereas EPI and SAS centres are located in the southern part of the city. However, only the Rywal Shopping Centre can be classified nie oraz dostęp do miejsc parkingowych. Wraz z rozwojem przestrzeni miejskiej, powstawaniem nowych osiedli mieszkaniowych, postępuje rozwój nowych obszarów podmiejskich, co dodatkowo zachęca inwestorów do lokalizowania swoich inwestycji poza strefą śródmieścia (Szulce 1998).

\section{Struktura sieci handlowej w mieście i jej roz- mieszczenie}

W Białej Podlaskiej znajduje się pięć centrów handlowych, trzy są zlokalizowane w śródmieściu i dwa w części południowej (rysunek 2). W części śródmiejskiej znajduje się Atrium, Drop oraz Rywal, natomiast w części południowej miasta położone są centra EPI i SAS. Jednak tylko Centrum Handlowe Rywal można zaliczyć do nowej generacji, gdzie występuje bogata

Table 1. Determinants of the location of the retail network

Tabela 1. Determinanty lokalizacji sieci handlowej

\begin{tabular}{|c|c|}
\hline $\begin{array}{l}\text { Group of factors/ } \\
\text { Grupa czynników }\end{array}$ & Specific factors/ Czynniki szczegółowe \\
\hline \multirow{4}{*}{$\begin{array}{l}\text { Demographic factors/ } \\
\text { Demograficzne }\end{array}$} & Population/Liczba ludności \\
\hline & Population density/ Gęstość zaludnienia \\
\hline & Differentiation by age and sex/ Zróżnicowanie według wieku i płci \\
\hline & Number and size of households/ Liczba i wielkość gospodarstw domowych \\
\hline \multirow{5}{*}{$\begin{array}{l}\text { Economic factors/ } \\
\text { Ekonomiczne }\end{array}$} & The level and dynamics of the buyers' income/ Poziom i dynamika dochodów nabywców \\
\hline & Potential and effective demand/ Popyt potencjalny i efektywny \\
\hline & Lifestyle and consumption model/ Styl życia i model konsumpcyjny \\
\hline & Economic stability of the region/ Stabilność ekonomiczna regionu \\
\hline & Unemployment rate/ Stopa bezrobocia \\
\hline \multirow{6}{*}{$\begin{array}{l}\text { Socio-cultural factors/ } \\
\text { Społeczno-kulturowe }\end{array}$} & Consumption model/ Model konsumpcji \\
\hline & Amount of free time/ Ilość wolnego czasu \\
\hline & Mentality of the society/ Mentalność społeczeństwa \\
\hline & Size of agglomeration/ Wielkość aglomeracji \\
\hline & Plans for spatial land development/ Plany przestrzennego zagospodarowania terenu \\
\hline & Type of architectural surroundings (density, age, style)/ Rodzaj zabudowy(gęstość, wiek, styl) \\
\hline \multirow{4}{*}{$\begin{array}{l}\text { Transport factors/ } \\
\text { Transportowe }\end{array}$} & $\begin{array}{l}\text { Level and dynamics of public transport development/ } \\
\text { Poziom i dynamika rozwoju transportu publicznego }\end{array}$ \\
\hline & $\begin{array}{l}\text { The level of vehicle availability in the target segment of buyers/ } \\
\text { Stopień zmotoryzowania docelowego segmentu nabywców }\end{array}$ \\
\hline & Favourable location and availability of car parks/ Dogodna lokalizacja i dostępność parkingów \\
\hline & $\begin{array}{l}\text { Availability of means of transport for suppliers and personnel/ Dostępność środków transportu } \\
\text { dla dostawców i personelu }\end{array}$ \\
\hline \multirow{3}{*}{$\begin{array}{l}\text { Factors related to the } \\
\text { competition/ } \\
\text { Związane z konkurencją }\end{array}$} & $\begin{array}{l}\text { The intensity of direct and indirect competition/ } \\
\text { Natężenie konkurencji bezpośredniej i pośredniej }\end{array}$ \\
\hline & $\begin{array}{l}\text { Opportunities and hazards arising from location next to existing competition/ } \\
\text { Szanse i zagrożenia wynikające z lokalizacji obok istniejącej konkurencji }\end{array}$ \\
\hline & Strategies used by local competitors/ Strategie stosowane przez lokalnych konkurentów \\
\hline \multirow{4}{*}{$\begin{array}{l}\text { Financial factors/ } \\
\text { Finansowe }\end{array}$} & Prices of land and real estate/ Ceny gruntów i nieruchomości \\
\hline & Costs of leasing and purchasing concessions/ Koszty leasingu i wykupu koncesji \\
\hline & $\begin{array}{l}\text { Costs of construction and modernisation of retail facilities/ } \\
\text { Koszty budowy i modernizacji obiektów handlowych }\end{array}$ \\
\hline & Costs of retail establishment security/ Koszty ochrony jednostki handlowej \\
\hline \multirow{3}{*}{$\begin{array}{l}\text { Legal factors/ } \\
\text { Prawne }\end{array}$} & Building regulations/ Przepisy budowlane \\
\hline & Permissions to open/launch a facility/ Zezwolenia na otwarcie jednostki \\
\hline & Regulations regarding shop opening hours/ Przepisy dotyczące czasu otwarcia sklepu. \\
\hline
\end{tabular}

Source: Szulce H. (1998), Struktury i strategie w handlu, PWE, p. 216.

Źródło: Szulce H. (1998), Struktury i strategie w handlu, PWE, s. 216. 
as a new generation establishment, with a wide range of commercial offers from boutiques through eateries to a cinema. Additionally, it is situated in an advantageous location, namely next to Plac Wolności, where most of public institutions are also located. EPI and SAS Shopping Centres are more modest in terms of their range of services. There is no cinema, nor are there a lot of various eateries or boutiques in those centres but there are construction-refurbishment profile shops and consumer electronics outlets. The Atrium and Drop Shopping Centres are even smaller than those mentioned above but are in a convenient location which contributes to heavy traffic. There is also a specialty department store Sawko in the city, owned by PSS "Społem", which specialises in clothing and footwear articles, household cleaning products and offers a wide range of utility glassware. oferta handlowa od butików po lokale gastronomiczne, a na kinie kończąc, dodatkowo znajduje się w korzystnym położeniu mianowicie przy Placu Wolności gdzie znajduje się większość instytucji publicznych. Centra Handlowe EPI oraz SAS są uboższe pod względem zakresu świadczenia usług. Nie ma w nich kina oraz wielu lokali gastronomicznych i butików, jednak znajdują się tam sklepy o profilu budowlano-remontowym oraz AGD/RTV. Centrum Handlowe Atrium i Drop, sa jeszcze mniejsze od wymienionych wyżej, ale znajdują się w dogodnej lokalizacji co przyczynia się do generowania dużego ruchu. W mieście znajduje się również Dom Handlowy Sawko, należący do PSS „Społem”, który specjalizuje się w branży odzieżowej, obuwniczej, chemii użytkowej oraz posiada bogata ofertę szkła użytkowego.

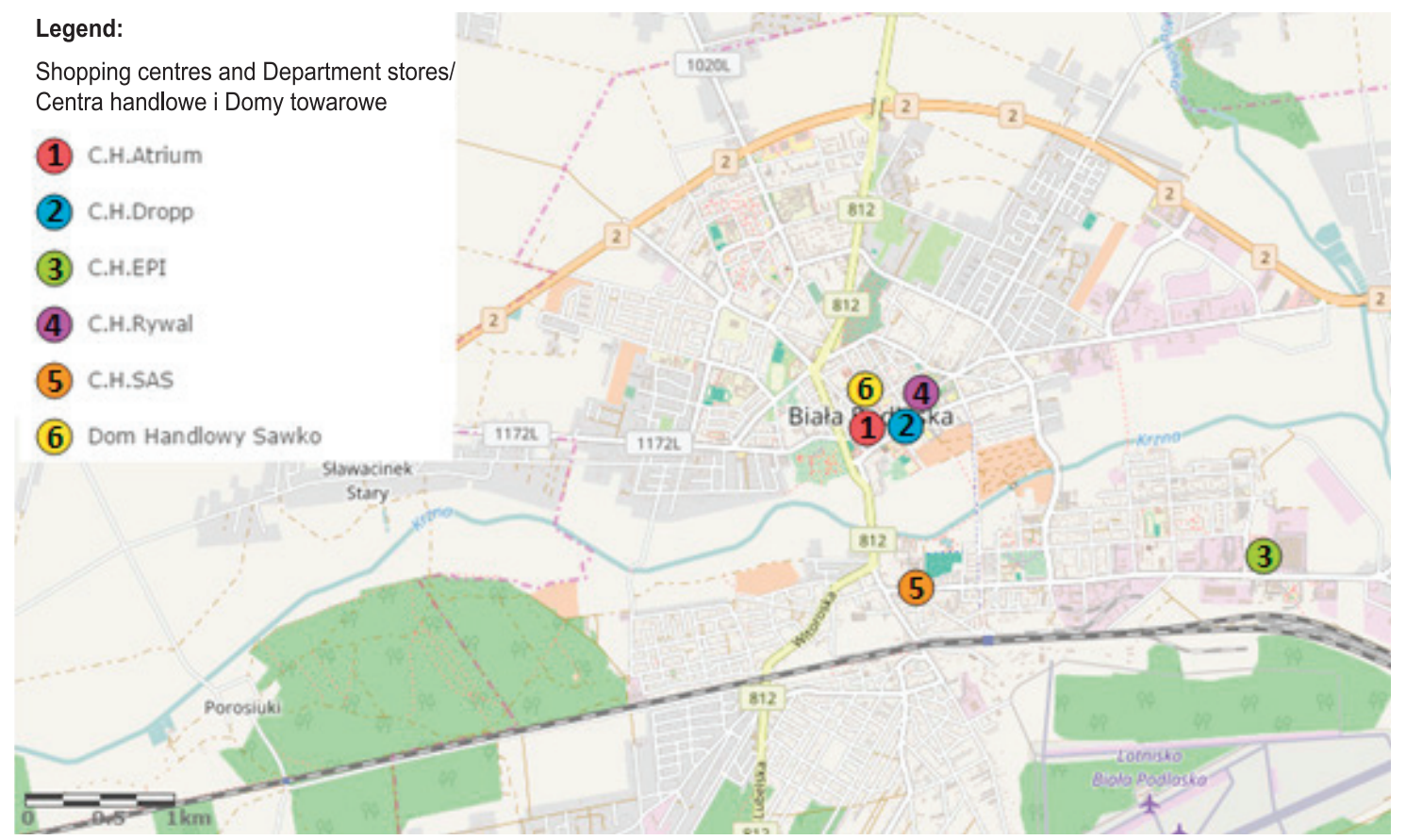

Figure 2. Location of shopping centres and department stores in Biała Podlaska

Rysunek 2. Lokalizacja centrów handlowych i domów towarowych w Białej Podlaskiej

Source: own elaboration.

Źródło: Opracowanie własne.

Other facilities of large-format retail trade are discount stores, supermarkets, hypermarkets and grocery stores; there are thirteen of them in Biała Podlaska (Figure 3). The discount stores include seven Biedronka and Lidl stores. Biedronka stores are spread all over the city and mainly concentrated near housing estates and in areas with heavy traffic. One of the newest discount stores was opened near the EPI Shopping Centre, which contributes to heavy traffic, and additionally the newly established facility is located near the Hall of Residence of Pope John Paul II State School of Higher Education in Biała Podlaska. Another discount store is located in the SAS Shopping Centre, and the other one near the ring road in the north of the city. The rest of the stores target their offer mainly at the residents of nearby estates. Lidl
Kolejnymi obiektami handlu wielkopowierzchniowego są dyskonty, supermarkety i hipermarkety spożywcze, w Białej Podlaskiej powstało ich trzynaście (rysunek 3). Do sklepów dyskontowych zaliczymy siedem sklepów Biedronka oraz Lidl-a, Biedronki rozsiane są na całej przestrzeni miasta, skupione są główne przy osiedlach mieszkalnych oraz w miejscach dużego natężenia ruchu, jeden z ostatnich dyskontów powstał przy C.H. EPI, które generuje duży ruch, dodatkowo nowopowstały obiekt znajduje się nieopodal Domu Studenta Państwowej Szkoły Wyższej im. Jana Pawła II w Białej Podlaskiej. Kolejny dyskont ulokowany jest w C.H. SAS, a inny znajduje się przy obwodnicy na północy miasta. Pozostałe swoja ofertę kierują głównie do mieszkańców pobliskich osiedli. Lidl położony jest w niedalekiej odległości od 
store is located at a short distance from the city centre, in close proximity to the sports and entertainment arena of the University of Physical Education and a concentration of detached houses.

Intermarche, Stokrotka and Aldik supermarkets are located at the junction of the main roads in Biała Podlaska (Artyleryjska, Zamkowa, Janowska and Piłsudskiego streets) in the inner centre of the city's transport network. The Stokrotka supermarket is located in the Rywal Shopping Centre, which features the highest natural retail traffic.

There are two facilities classified as hypermarkets in Biała Podlaska - Carrefour and Kaufland. Carrefour is located in close proximity to the ring road; additionally, there is a new housing estate being built nearby, and the hypermarket is situated in the proximity to the Shell Petrol Station, McDonald's restaurant, Media Expert consumer electronics supermarket and Bricoman construction materials superstore. Kaufland, on the other hand, is located in the south of the city and features large car park and convenient public transport connections.

Another form of large-format retail trade are large specialist stores which include non-food consumer and investment products. We can distinguish here the following large stores: clothing - Tania Odzież, Textilmarket and Cameleon; construction materials - Bricoman and PSB Mrówka; consumer electronics and household goods - Media Expert and Neonet, and home furnishing stores - Jysk and Pepco. ścisłego centrum miasta, w bliskim sąsiedztwie hali widowiskowo-sportowej AWF, oraz skupiska domów jednorodzinnych.

Supermarkety Intermarche, Stokrotka i Aldik położone są przy skrzyżowaniu ważniejszych dróg w Białej Podlaskiej (Artyleryjskiej, Zamkowej oraz Janowskiej i Marszalka Piłsudskiego) w ścisłym centrum komunikacyjnym miasta. Stokrotka położona jest w C.H. Rywal gdzie występuje największy naturalny ruch handlowy.

W Białej Podlaskiej są dwa obiekty zaliczane do hipermarketów - a mianowicie Carrefour i Kaufland. Carrefour znajduje się w bliskim sąsiedztwie z obwodnicą dodatkowo w pobliżu tego terenu powstaje nowe osiedle mieszkaniowe a sam hipermarket położony jest w pobliżu stacji paliw Shell, restauracji McDonald's, supermarketu AGD/RTV Media Expert i marketu budowlanego Bricoman. Kaufland natomiast znajduje się w południowej części miasta, posiada duży parking i dogodne połączenie komunikacji miejskiej.

Inną formą handlu wielkopowierzchniowego są markety, które obejmują nieżywnościowe towary konsumpcyjne i inwestycyjne. Wyróżnić możemy tutaj markety: odzieżowe - Tania Odzież, Textilmarket i Cameleon; budowlane - Bricoman i PSB Mrówka; AGD/RTV - Media Expert i Neonet, oraz sklepy z wyposażeniem dla domu - Jysk i Pepco.

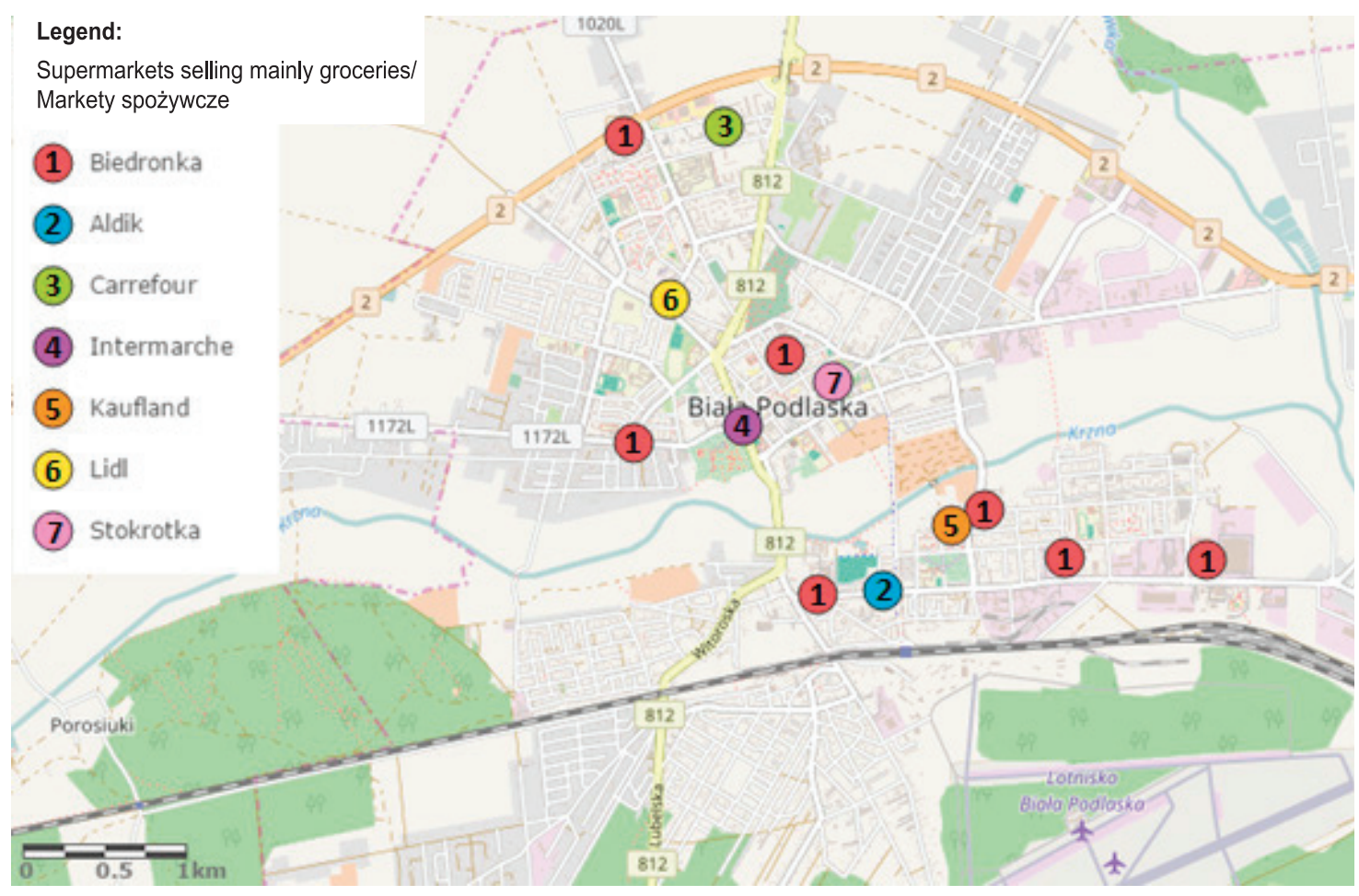

Figure 3. Location of grocery stores in Biała Podlaska

Rysunek 3. Lokalizacja marketów spożywczych w Białej Podlaskiej

Source: own elaboration.

Źródło: Opracowanie własne. 


\section{Mutual interaction between the objects of the city's retail network}

Small shops in the city have difficulties in competing with large-format retail establishments as the main factor influencing the decision where to do the shopping is the price. Large-format retail facilities attract customers with their bargain prices, particularly for goods intended for day-today consumption which are considered as basic ones (everyday necessities). Low prices in LFR establishments attract and intercept customers of small shops, despite their repeated declarations of willingness to support local enterprises. In LFR customers often take advantage of current promotions.

According to the research, about $75 \%$ of customers try to buy goods at promotional prices. However, only $17 \%$ actively browses the flyers from various stores in search of the right offer. Low prices can compensate any other discomfort that hinders purchases in largeformat retail facilities such as: long queues at the checkout or crowded conditions at the stalls.

The wide assortment structure offered in largeformat stores allows one to save time and makes shopping convenient. Being able to pay by credit card is also a significant facility.

Most LFR facilities are located at easily accessible communication routes. Each of the stores has a large car park capable of servicing many customers. Such form of shopping is a response to the growing rate of vehicle availability in the city (Wygnański 2006).

An important factor when choosing a store is the distance between the sale outlet and the place of residence. Most of the surveyed city residents declare that within $750 \mathrm{~m}$ from their place of residence there is at least one LFR facility. Such declaration was made by $87 \%$ of the respondents (table 2 ).

In relation to local groceries, $73 \%$ of the inhabitants declare that they are located up to $150 \mathrm{~m}$ away, and only $22 \%$ declare that they are further than $200 \mathrm{~m}$ away. More than $40 \%$ of the city's respondents declare that in order to do the shopping they cover a distance of up to $1 \mathrm{~km}$, and $32 \%$ of them over $2 \mathrm{~km}$. The most popular form of reaching retail outlets is a trip on foot (36\%), car transport accounts for a large

\section{Wzajemne oddziaływanie obiektów sieci handlo- wej miasta}

Małe sklepy w mieście mają trudności z konkurowaniem z wielkopowierzchniowymi palcówkami handlu, ponieważ głównym czynnikiem wpływającym na wybór miejsca dokonywania zakupów jest cena. Obiekty handlu wielko powierzchniowego przyciągają klientów swoimi atrakcyjnymi cenami szczególnie towarów przeznaczonych do codziennego użytku, które są traktowane jako podstawowe (pierwszej potrzeby). Niskie ceny towarów w WOH przyciągają i przechwytują klientów małych sklepów, mimo że często deklarują chęć wspierania lokalnej przedsiębiorczości. W WOH klienci często korzystają $\mathrm{z}$ aktualnych promocji.

Jak wynika z badań około 75\% klientów stara się kupować towary w promocyjnych cenach. Jednak zaledwie $17 \%$ aktywnie przegląda oferty różnych sklepów w poszukiwaniu odpowiedniej dla nich promocji. Niskie ceny mogą równoważyć wszelkie inne niewygody, które utrudniają zakupy w sklepach wielkopowierzchniowych takie, jak: długie oczekiwanie w kolejkach przy kasie czy tłok przy stoiskach.

Szeroka struktura asortymentowa oferowana w sklepach wielkopowierzchniowych umożliwia oszczędność czasu i wygodę dokonywania zakupów. Istotnym ułatwieniem jest też możliwość płacenia kartą kredytową.

Większość WOH jest lokalizowana przy łatwo dostępnych szlakach komunikacji miejskiej. Każdy ze sklepów posiada duże parkingi zdolne obsłużyć wielu klientów. Taka forma dokonywania zakupów jest odpowiedzią na rosnący wskaźnik motoryzacji w mieście (Wygnański 2006).

Ważnym czynnikiem przy wyborze miejsca zakupów jest odległość między punktem sprzedaży a miejscem zamieszkania. Większość badanych mieszkańców miasta deklaruje, iż w odległości do $750 \mathrm{~m}$ od miejsca zamieszkania znajduje się jakiś WOH. Taką deklarację wyraziło 87\% ankietowanych (tabela 2).

W stosunku do osiedlowych sklepów spożywczych 73\% mieszkańców deklaruje, że posiada je w odległości do $150 \mathrm{~m}$ a tylko $22 \%$ w odległości przekraczającej 200 metrów. Ponad 40\% ankietowanych mieszkańców miasta deklaruje, iż dla dokonania za-

Table 2. The straight-line distance between the place of residence and the store and the actual distance to cover

Tabela 2. Odległość miejsca zamieszkania od miejsc dokonywania zakupów i dystans do pokonania

\begin{tabular}{|c|c|c|c|c|c|}
\hline $\begin{array}{c}\text { The distance to the } \\
\text { nearest LFR store in } \\
\text { metres/ } \\
\text { Odległość od najbliższe- } \\
\text { go WOH w metrach }\end{array}$ & $\begin{array}{c}\text { Votes/ } \\
\text { Głosów }\end{array}$ & $\begin{array}{c}\text { The distance to the ne- } \\
\text { arest shop (in metres)/ } \\
\text { Odległość od najbliższe- } \\
\text { go sklepu(w metrach) }\end{array}$ & $\begin{array}{c}\text { The distance to cover } \\
\text { Using means of commu- } \\
\text { nication (in metres)/ } \\
\text { Gdlesów } \\
\text { Odległóc do pokonania } \\
\text { środkami komunikacji } \\
\text { (w metrach) }\end{array}$ & $\begin{array}{c}\text { Votes/ } \\
\text { Głosów }\end{array}$ \\
\hline Up to/ Do 250 & 18 & Up to/ Do 50 & 14 & Up to/ Do 500 & 23 \\
\hline $250-500$ & 23 & $50-100$ & 36 & $500-1,000$ & 18 \\
\hline $500-750$ & 46 & $100-150$ & 23 & $1,000-1,500$ & 9 \\
\hline $750-1,000$ & 5 & $150-200$ & 5 & $1,500-2,000$ & 18 \\
\hline More than/ Ponad 1,000 & 8 & More than/ Ponad 200 & 22 & More than/ Ponad 2,000 & 32 \\
\hline
\end{tabular}

Source: own elaboration.

Źródło: Opracowanie własne. 
share (34\%), as well as public transport (22\%), while just over $7 \%$ of shoppers use a bike or scooter for this purpose.

Based on the conducted studies, maps showing the range of the interaction between the chosen retail facilities and customers from Biała Podlaska were created (Figure 4). For LFR facilities specialising in the sale of food products, the distance of about 1 $\mathrm{km}$ was adopted; smaller groceries were assigned a range of $250 \mathrm{~m}$, while shopping centres about $2 \mathrm{~km}$. As Figure 3 demonstrates, some large-format retail objects are located within a short distance from each other, hence they have to compete with one another for the interaction zone with potential buyers. The competition of Kaufland with Biedronka, Aldik with Biedronka and Intermarche, Stokrotka with Biedronka are examples from Biała Podlaska. The first two are about 200 meters away from each other. The location of the hypermarket as well as the discount store is convenient because they are located at one of the three streets connecting the city centre with the southern part. The people returning from work or those who have to deal with some administrative matters have a choice between the two supermarkets, which intensifies the battle for customers between them. The next pair located at a short distance from one another is Biedronka and Aldik. The former is located in the SAS shopping centre, which contributes to Biedronka's large number of customers and its high revenues. Aldik is in a similar situation as the first pair because it is located at the second road linking the city centre and the southern part. Additionally, it is situated at the crossroads of ulica Sidorska and Aleja Tysiąclecia. In spite of the fact that ulica Sidorska is the main street in the southern part of the city, Aldik's disadvantage lies in a small number of parking spaces. The last group struggling to attract buyers is Intermarche, Stokrotka and Biedronka. These three markets are located in the very centre of the city. Stokrotka is located in the Rywal shopping centre which draws large numbers of customers and is a natural traffic generator. Intermarche is situated at the crossroads of two main streets. As there are many parking spaces, people returning from work do not have to be held up in rush hour traffic jams in other side streets. Instead, they are able to make purchases travelling along the main road. Of the two mentioned, the lowest attendance rates are recorded by Biedronka, which is located next to the municipal market and the prison. There are no major housing estates in this area.

Supermarkets also compete with smaller chains of shops. Figure 5 shows the areas where a given type of shop dominates. As can be seen, two Społem shops, two Lewiatan shops and one Delikatesy Centrum shop operate on the outskirts of the city or close to housing estates where no large-format retail facility has yet been built. Until recently, two more Lewiatan and the Delikatesy Centrum stores attracted buyers from a housing estate in the south-east of the city. Recently, a Biedronka discount store has been built there, which will reduce the revenues and the number of customers. Situated in an interesting location kupów pokonuje odległość do $1 \mathrm{~km}$, a $32 \%$ ponad 2 $\mathrm{km}$. Najpopularniejszą formą dotarcia do punktów handlowych są podróże piesze (36\%), duży udział przypada transportowi samochodowemu (34\%) oraz komunikacji miejskiej (22\%), a niewiele ponad 7\% osób udających się na zakupy wykorzystuje w tym celu rower lub skuter.

Na podstawie przeprowadzonych badań zostały stworzone mapy zasięgu oddziaływania wybranych obiektów handlowych na klientów w mieście Biała Podlaska (rysunek 4). Dla WOH specjalizujących się w sprzedaży produktów żywnościowych została przyjęta odległość około $1 \mathrm{~km}$, mniejsze sieciowe sklepy spożywcze otrzymały zasięg $250 \mathrm{~m}$, natomiast centra handlowe około $2 \mathrm{~km}$. Jak widać na rysunku 3, niektóre obiekty handlu wielkopowierzchniowego muszą ze sobą konkurować o strefę oddziaływania na potencjalnych nabywców ponieważ są zlokalizowane w niewielkiej odległości od siebie. Przykładem z Białej Podlaskiej będzie Kuafland z Biedronką, Aldik z Biedronką, oraz Intermarche, Stokrotka i Biedronka. Pierwsza para znajduje się w odległości około 200 metrów, lokalizacja hipermarketu jak i dyskontu jest dogodna ponieważ znajdują się przy jednej z trzech ulic łączących śródmieście z południową częścią, osoby wracające po pracy lub takie, które muszą załatwić jakieś sprawy administracyjne mają do wyboru jeden z dwóch marketów co zaostrza między nimi walkę o klientów. Kolejną parą położoną w niedużej odległości jest Biedronka i Aldik, Biedronka jest zlokalizowana w C.H. SAS co przyczynia się do generowania jej dużego ruchu i obrotów, natomiast Aldik jest w podobnej sytuacji jak pierwsza para ponieważ znajduje się przy drugiej drodze łączącej strefę śródmiejską i południową, dodatkowo znajduje się przy skrzyżowaniu ulicy Sidorskiej i alei Tysiąclecia, ulica Sidorska stanowi główną ulice w części południowej miasta, jednak minusem marketu Aldik jest mała ilość miejsc parkingowych. Ostatnia grupą walczącą o przyciąganie nabywców jest Intermarche, Stokrotka oraz Biedronka, te trzy markety znajdują się w ścisłym centrum miasta Stokrotka jest ulokowana w C.H. Rywal co przyciąga duże ilości klientów oraz centrum jest naturalnym generatorem ruchu, Intermarche znajduje się przy skrzyżowaniu głównych ulic, supermarket posiada dużą liczbę miejsc parkingowych co sprawia, że osoby wracające z pracy nie muszą stać w korkach w godzinach szczytu w innych uliczkach tylko są w stanie dokonać zakupów jadąc główną drogą. Z dwóch wymienionych najmniejszą frekwencję posiada dyskont Biedronka, który znajduje się obok targowiska miejskiego oraz zakładu karnego, na tym obszarze nie występują większe osiedla mieszkaniowe.

Sklepy wielkopowierzchniowe konkurują też z mniejszymi sieciami sklepów. Na rysunku 5 przedstawiono obszary dominacji określonego rodzaju sklepu. Jak widać dwa sklepy Społem, dwa sklepy Lewiatan oraz jeden sklep Delikatesy Centrum działają na obrzeżach miasta lub przy osiedlach mieszkaniowych, a więc tam gdzie nie powstał jeszcze żaden obiekt wielkopowierzchniowy. Do niedawna jeszcze dwa sklepy sieci Lewiatan oraz Delikatesy Centrum 
are eleven Społem shops. Six of them are situated in the very centre of the city, among three large supermarkets. The next five Społem shops are also within a short distance of the supermarkets. Such an arrangement contributes to intensifying competition and to using aggressive marketing policies by retail establishments. The customers of the analysed facilities should be satisfied with this situation. On the other hand, such a state of affairs is undoubtedly a significant problem for businesses.

The last analysis concerns the shopping centres located within Biała Podlaska. In order to shop for nonfood items unavailable in other LRF establishments of hypermarket, supermarket or discount store kind, the residents look for such opportunities in specialist shops or in shopping centres (SC). The impact area of such facilities is considerably greater than that of other LFR forms. In addition, each SC has a different assortment, which contributes to attracting customers from remote parts of the city. The greatest concentration and competition occurs in the downtown part of Biała Podlaska, because there are three SC and one department store. Located in the southern part of town and the most distant from each other EPI and SAS shopping centres are the least affected by the competition (Figure 6). They are also a natural generator of commercial traffic in those areas, which contributes to the development of small specialist shops that complement the offer przyciągnęły nabywców z osiedla mieszkaniowego na południowym wschodzie miasta. Niedawno powstał tam dyskont Biedronka, który przyczyni się do zmniejszenia obrotów i obsługiwanych klientów. Ciekawą lokalizację posiada jedenaście sklepów Społem, sześć z nich jest położona $\mathrm{w}$ ścisłym centrum miasta pośród trzech dużych marketów, kolejne pięć sklepów Społem również znajduje się w niedużej odległości od marketów. Taki układ przyczynia się do wzmocnienia konkurencji i stosowania agresywnej polityki marketingowej przez placówki handlowe, klienci analizowanych placówek powinni być zadowoleni takiej sytuacji. Natomiast dla przedsiębiorstw taki stan rzeczy bez wątpienia jest istotnym problemem.

Ostatnia analiza dotyczy centrów handlowych znajdujących się na terenie miasta Biała Podlaska. Mieszkańcy w celu dokonania zakupów artykułów nieżywnościowych, których nie dostaną w pozostałych WOH typu hipermarket, supermarket czy dyskont,poszukują w sklepach specjalistycznych lub w centrach handlowych (C.H.). Strefa oddziaływania takich obiektów jest znacznie większa w porównaniu do pozostałych form WOH, ponadto każde z C.H. posiada inną ofertę asortymentową, co sprzyja pozyskiwaniu klientów z odległych części miasta. Największe zagęszczenie oraz konkurencja występuje w śródmiejskiej części Białej Podlaskiej, ponieważ znajdują się tam, aż trzy C.H. oraz jeden dom handlowy, niewielką konkurencję odczuwają najbar-

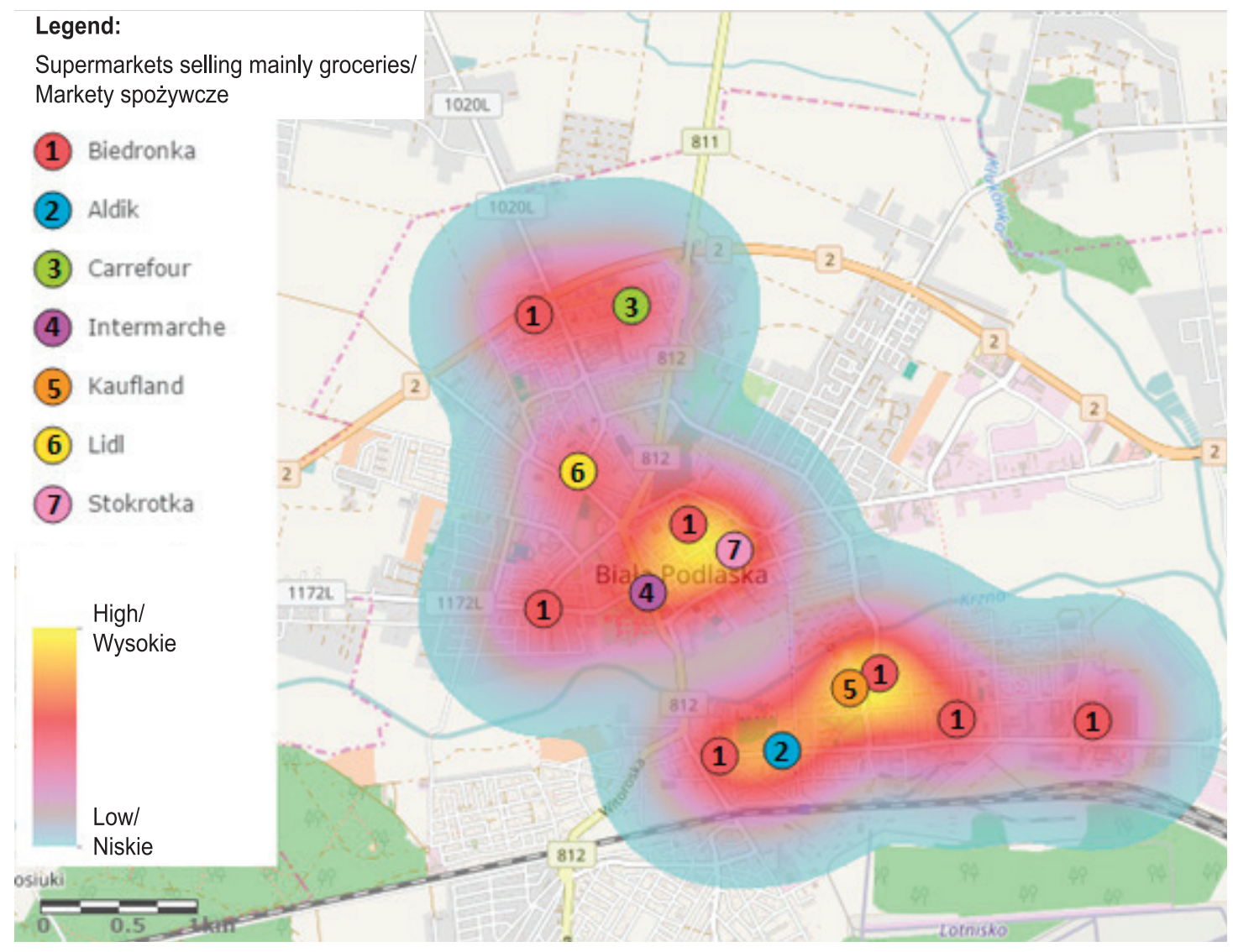

Figure 4. The interaction between large-format retail facilities in Biała Podlaska

Rysunek 4. Odziaływanie obiektów handlu wielkopowierzchniowego na siebie w Białej Podlaskiej Source: own elaboration.

Źródło: Opracowanie własne. 


\section{Legend:}

Supermarkets selling mainly groceries/ Markety spożywcze

Biedronka
Aldik
Carrefour
Intermarche
Kaufland
Lidl
Stokrotka

Other grocery chain stores/ Inne sieci spożywcze

$\diamond$ Spolem

$\diamond$ Delikatesy Centrum

$\diamond$ Lewiatan
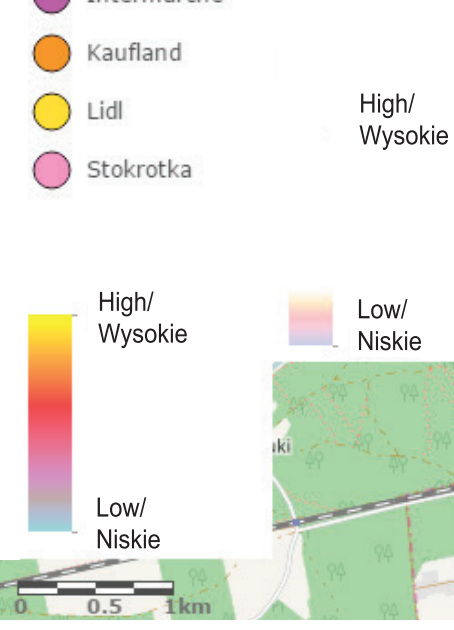

\section{High/}

Wysokie

(1)
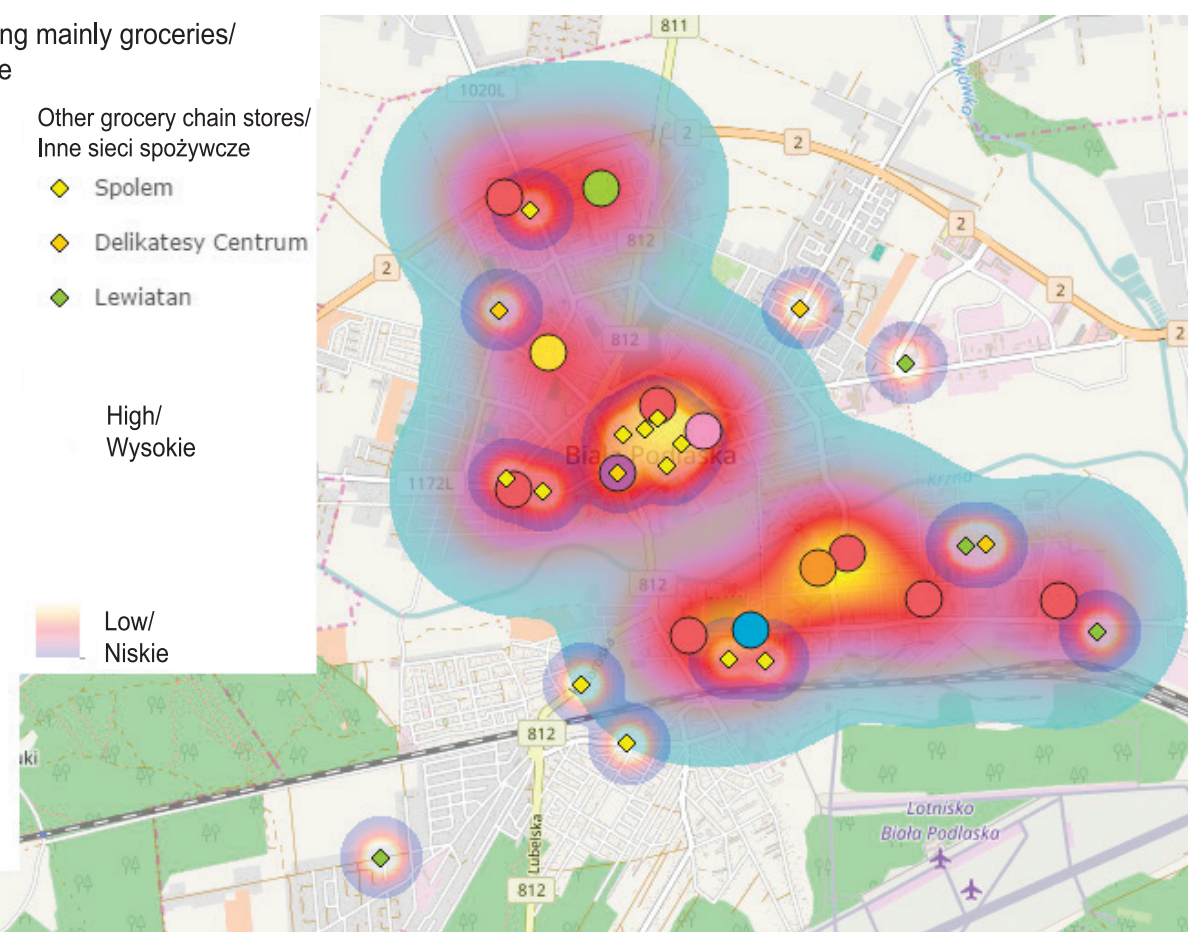

Figure 5. The interaction between supermarkets and smaller food chains in Biała Podlaska Rysunek 5. Odziaływanie na siebie marketów oraz mniejszych sieci spożywczych w Białej Podlaskiej Source: own elaboration.

Źródło: Opracowanie własne.

Legend:
Shopping centres
and Department stores/
Centra handlowe
i Domy towarowe
Interaction/ Oddziaływanie
High/
Wysokie
Low/
(1) C.H.Atrium
(2) C.H.Dropp
(3) C.H.EPI
(4) C.H.Rywal
(5) C.H.SAS
(6) Dom Handlowy Sawko
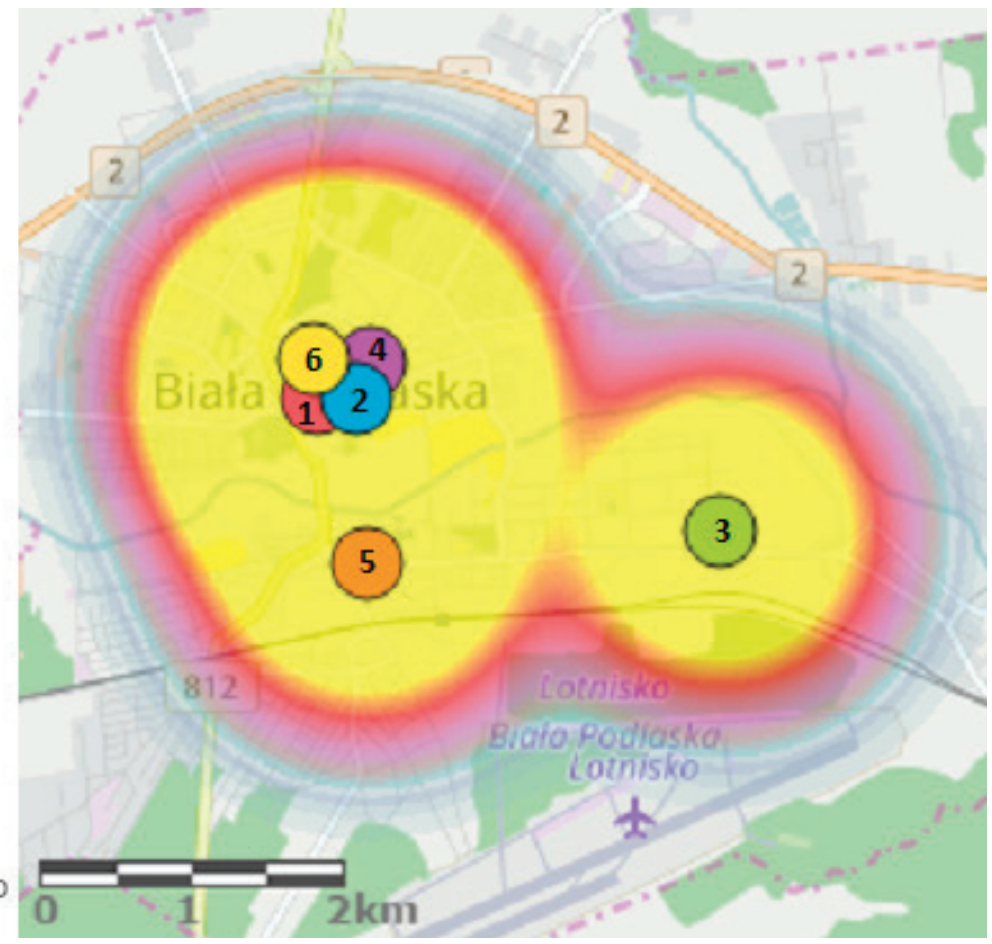

Figure 6. The interaction of the SCs in Biała Podlaska Rysunek 6. Odziaływanie na siebie C.H. w Białej Podlaskiej Source: own elaboration.

Źródło: Opracowanie własne. 
of the listed SCs. In the town centre, residents are most likely to visit Rywal, Atrium, Drop and Sawko shopping centres, while in the southern part of the city the most popular ones are EPI (in the east) and SAS (in the west) shopping centres.

\section{The perspectives of retail network development in Biała Podlaska}

Biała Podlaska currently has about 78 thousand $\mathrm{m}^{2}$ of sales area, ranging from small shops, located in residential buildings, to independent largeformat retail facilities. Due to technical or sanitary considerations, some small shops are unable to meet the requirements for continuing retail operations. Their closure will result in further loss of sales area with shrinkage reaching up to as much as $10 \%$ of the current area.

At present, the sales area in Biała Podlaska is about $700 \mathrm{~m}^{2}$ per 1000 inhabitants of the city. This is only slightly less than in other similar Polish cities. Taking into account the expected sales area losses in the next 5-10 years, and the increased number of customers being serviced, it is estimated that to meet the expectations of buyers, the sales area should be increased by approximately $20000 \mathrm{~m}^{2}$.The anticipated increase in the number of buyers is not caused by the increasing number of city dwellers (as a result of natural demographic processes), but rather it is due to the influx of external buyers. The spatial layout and the condition of the existing shopping centre facilities allow for their extension and revitalisation of their surroundings. The improvement of the aesthetics and functionality of these centres should be incorporated into the set of urban policy objectives. This applies to both parts of the city. The need to expand and improve the quality of shopping centres and create new largeformat retail facilities is also due to the expectations of young people who have higher demands and who expect better living conditions in their own city. Older people have no objections to shopping on bazaars or small local shops, which do not ensure comfort.

Biała Podlaska is the first major city for buyers from Belarus in this part of Poland. Visa abolition and liberalisation of cross-border travel will increase the number of foreign buyers. The modern, attractive and well-functioning retail trade in Biała Podlaska may be an important factor in the development of cross-border relations, which are beneficial for both countries. dziej oddalone od siebie C.H. EPI oraz C.H. SAS, położone w południowej części miasta (rysunek 6). Są one również naturalnym generatorem ruchu handlowego w tamtych obszarach co przyczynia się do rozwoju małych sklepów specjalistycznych, które stanowią uzupełnienie oferty wymienionych C.H. W części śródmiejskiej miasta mieszkańcy najczęściej i najchętniej korzystają z oferty C.H. Rywal, C.H. Atrium, C.H. Drop, oraz z Domu Handlowego Sawko, natomiast w cześci południowej miasta największą popularnością cieszy się na wschodzie C.H. EPI, a na zachodniej C.H. SAS.

\section{Perspektywy rozwoju sieci handlowej w mieście Biała Podlaska}

Biała Podlaska obecnie posiada około 78 tysięcy $\mathrm{m}^{2}$ powierzchni sprzedażowej, rozpoczynając od małych sklepów, zlokalizowanych w budynkach mieszkalnych, po samodzielne obiekty handlu wielkopowierzchniowego. Część małych sklepów nie jest w stanie spełnić warunków wymaganych do kontynuowania działalności jaką jest handel detaliczny ze względów technicznych lub sanitarnych. Ich zamknięcie spowoduje dalsze ubytki w powierzchni sprzedażowej, które będą sięgały nawet do 10\%. aktualnej powierzchni.

Aktualnie powierzchnia sprzedażowa w Białej Podlaskiej wynosi około $700 \mathrm{~m}^{2} \mathrm{w}$ przeliczeniu na 1000 mieszkańców miasta. Jest to tylko nieznacznie mniej niż w innych podobnej wielkości miastach Polski. Biorąc pod uwagę przewidywane ubytki powierzchni w następnym okresie 5 - 10 lat oraz zwiększoną liczbę obsługiwanych klientów szacuje się, że aby sprostać oczekiwaniom nabywców powierzchnia sprzedażowa powinna powiększyć się o około 20 tys. $\mathrm{m}^{2}$. Przewidywane zwiększenie liczby nabywców nie wynika ze zwiększenia liczby mieszkańców miasta w wyniku naturalnych procesów demograficznych lecz raczej z powodu napływu nabywców zewnętrznych. Układ przestrzenny i stan obiektów istniejących centrów handlowych pozwala na rozbudowę niektórych z nich i rewitalizację ich otoczenia. Poprawę estetyki i funkcjonalności tych centrów należałoby wprowadzić do zestawu celów polityki samorządu miejskiego. Dotyczy to obydwu części miasta. Potrzeba rozbudowy i poprawy jakości CH i powstania nowych obiektów handlu wielkopowierzchniowego wynika także z oczekiwań ludzi młodych, którzy mają wyższe wymagania i oczekują poprawy warunków życia we własnym mieście. Ludzie starsi korzystają bez oporów z zakupów na bazarach czy w małych nie zapewniających komfortu sklepach osiedlowych.

Miasto Biała Podlaska jest pierwszym większym miastem dla nabywców z Białorusi w tej części Polski. Zniesienie wiz wjazdowych i liberalizacja podróży transgranicznych spowoduje zwiększenie liczby nabywców zagranicznych. Nowocześnie zorganizowany, atrakcyjny i dobrze funkcjonujący handel detaliczny w Białej Podlaskiej może być ważnym czynnikiem rozwoju stosunków transgranicznych, korzystnych dla obydwu krajów. 


\section{Conclusion}

The dynamic development of retail trade in Poland continues, but this dynamic moves from large cities to smaller ones. With the expansion of retail space, changes in the structure of shopping facilities and forms of operation are taking place and the quality of service is improving. Modern, large-format retail facilities; supermarkets, hypermarkets and discount stores, while expanding territorially in smaller towns, reduce their retail space to customise it to the needs and realities of a given area. Specialty department stores and typical department stores are also loosing importance and also smaller retail outlets which are unable to cope with strong competition are in decline.

The ability to provide services to an intensified traffic of buyers, and the wide assortment of products on sale may ensure the development of large-format forms of retail space, especially shopping centres located in areas of high population density. While expanding the retail network, it is necessary to consider the demand for retail space and access to this location. Good public transport connections, the capacity of car parks, aesthetics of the facility and convenience of shopping are crucial. The coming years will be favourable for the further development of new investments and expansion of the existing retail space in the cities along Poland's eastern border.

In Biała Podlaska, during the transformation period, retail infrastructure developed, including modern large-format retail facilities and shopping centres that effectively compete with traditional facilities. It is forecasted that the number of outlets and sales figures in local shops and bazaars will be reduced. In order to improve customer service conditions, new retail stores will be developed in the form of large-format stores. An increase in the assortment structure and improvement of the customer service quality in shopping centres should be implemented. An Improvement in the provision of services to the increased cross-border traffic should be an important factor in the development of retail trade in the future.

There is a need to further concentrate commercial activity in the existing shopping centres, but at the same time it is necessary to have a functional and qualitative revitalisation of these shopping facilities and their surroundings. Also, there is a need to create better connections between these facilities and population centres in housing estates. It is necessary to ensure efficient transportation links with out-oftown housing estates.

\section{Podsumowanie}

Dynamiczny rozwój handlu detalicznego w Polsce jest kontynuowany, jednak ta dynamika przenosi się z dużych miast do miast mniejszych. Wraz z powiększaniem powierzchni handlowej dokonują się zmiany w strukturze obiektów handlowych i formach funkcjonowania oraz poprawia się jakość obsługi. Nowoczesne, wielkopowierzchniowe obiekty handlowe; supermarkety, hipermarkety i dyskonty, prowadząc ekspansję terytorialną w mniejszych miastach zmniejszają swoją powierzchnię handlową, aby dostosować się do zapotrzebowania oraz realiów panujących w danym terenie. Na znaczeniu tracą również domy handlowe oraz domy towarowe, a wraz z nimi podupadają mniejsze placówki handlowe, które nie są w stanie sprostać silnej konkurencji.

Zdolność obsługi wzmożonego ruchu nabywców oraz szeroki asortyment oferowanych do sprzedaży produktów może zapewnić rozwój form wielkopowierzchniowych przestrzeni handlowej, w tym zwłaszcza centrów handlowych zlokalizowanych w miejscach dużego zagęszczenia liczby mieszkańców. Przy rozbudowie sieci handlowej należy brać pod uwagę zapotrzebowania na przestrzeń handlową $\mathrm{w}$ danym miejscu oraz komunikacyjny dostęp do tego miejsca. Kluczowe znaczenie mają dobre połączenia komunikacji miejskiej, pojemność parkingów, estetyka obiektu oraz wygoda dokonywania zakupów. Najbliższe lata będą sprzyjały dalszemu powstawaniu nowych inwestycji i rozbudowie istniejącej przestrzeni handlowej w miastach wzdłuż wschodniej granicy Polski.

W mieście Biała Podlaska, w okresie transformacji rozwinęła się infrastruktura handlu detalicznego, w tym powstały nowoczesne obiekty handlu wielkopowierzchniowego i centra handlowe skutecznie konkurujące z obiektami tradycyjnymi. Przewiduje się, że liczba punktów sprzedaży i sprzedaż w sklepach osiedlowych i na bazarach będzie ograniczana. Dla poprawy warunków obsługi klientów będą powstały nowe obiekty handlowe w postaci sklepów wielkopowierzchniowych. Powinno nastąpić wzbogacenie struktury asortymentowej i poprawa jakości obsługi w centrach handlowych. Ważnym czynnikiem dalszego rozwoju handlu w przyszłości powinna być poprawa obsługi zwiększonego ruchu transgranicznego.

Istnieje potrzeba większego skupiania działalności handlowej $\mathrm{w}$ istniejących centrach handlowych ale jednocześnie potrzeba funkcjonalnej i jakościowej rewitalizacji tych obiektów handlowych oraz ich otoczenia, a także lepszego powiązania tych obiektów ze skupiskami ludności na osiedlach mieszkaniowych. Niezbędne jest zapewnienie sprawnych połączeń komunikacyjnych z osiedlami poza miastem.

\section{References/Literatura:}

1. Adamowicz M. (2015), Przekształcenia w sektorze handlu detalicznego i strategiach przedsiębiorstw na rynkach towarów konsumpcyjnych $w$ Polsce. Handel Wewnętrzny, nr 5, s. 7-11.

2. Adamowicz M., Zaręba M. (2015), New forms of retail trade in large and small towns in Poland/ Nowe formy handlu detalicznego w dużych i małych miastach Polski. Economic and Regional Studies, vol. 8, no. 4, s. 5-27. 
3. Adamowicz M., Zaręba M. (2015), Rozwój nowoczesnych powierzchni handlu detalicznego w dużych miastach Polski. Marketing i Rynek, nr 11, s. 27-39.

4. Faliński A. (2014), Rola handlu w polskiej transformacji gospodarczej, W: Znaczenie handlu w gospodarce narodowej. Polska Organizacja Handlu i Dystrybucji, Warszawa, s. 4-7.

5. GUS Bank Danych Regionalnych, faktyczne miejsce zamieszkania (z dnia 12.11.2016).

6. Kaczmarek T., Szafrański T. (2007), Poziom rozwoju i struktura przestrzenna handlu detalicznego w Poznaniu. Uniwersytet im. Adama Mickiewicza, Poznań.

7. Kłosiewicz-Górecka U. (2014), Zmiany w handlu w okresie spowolnienia gospodarczego. Marketing i Rynek, nr 7, s. 2-4.

8. Kościcka-Gębska M., Tul-Krzyszczuk A., Gębski J. (2009), Handel detaliczny żywnością w Polsce. Wydawnictwo SGGW, Warszawa,

9. Kucharska B., Twardzik M. (2007), Koncentracja i integracja w handlu. Aspekt teoretyczny. Wyższa Szkoła Biznesu, Dąbrowa Górnicza.

10. Kucharska B. (red.) (2010), Obsługa klienta w przedsiębiorstwie handlu detalicznego. Wydawnictwo Akademii Ekonomicznej w Katowicach, Katowice.

11. Pilarczyk B., Sławińska M., Mruk H. (2001), Strategie marketingowe przedsiębiorstw handlowych. Polskie Wydawnictwo Ekonomiczne S.A., Warszawa.

12. Powęska H. (2014), Udział nierejestrowanych zakupów artykułów nieżywnościowych w obrotach handlowych Polski z Ukraina, Białorusiq i Rosja. Stowarzyszenie Ekonomistów Rolnictwa i Agrobiznesu, Roczniki Naukowe, tom XVI zeszyt 3, s. $236-241$.

13. Zakrzewski Z. (red.) (1989), Ekonomika handlu wewnętrznego. Państwowe Wydawnictwo Ekonomiczne, Warszawa.

14. Sławińska M. (1989), Ekonomika handlu wewnętrznego. PWE, Warszawa.

15. Studium uwarunkowań i kierunków zagospodarowania przestrzennego miasta Biała Podlaska z dnia 27 listopada 2015 r., s. 88-89.

16. Szczepankiewicz W. (2011), Funkcjonowanie sektora handlu w łańcuchach dostaw. Wydawnictwo Difin, Warszawa.

17. Sulivan M., Adcock D. (2003), Marketing w handlu detalicznym. Oficyna Ekonomiczna, Kraków.

18. Szulce H. (1998), Struktury i strategie w handlu. PWE, Warszawa,

19. Szulce H., Chwałek J., Ciechomski W. (2008), Ekonomika handlu część 1. WSIP, Warszawa.

20. Wrzesińska J. (2008), Rozwój wielkopowierzchniowych obiektów handlowych w Polsce. Katedra Ekonomii i Polityki Gospodarczej SGGW, Warszawa.

21. Wygnański T. (2006), Polacy lubiq małe sklepy. Media \& Marketing Polska. 